\title{
Local and systemic gene expression responses of Atlantic salmon (Salmo salar L.) to infection with the salmon louse (Lepeophtheirus salmonis)
} Stanko Skugor*1, Kevin Alan Glover ${ }^{2}$, Frank Nilsen ${ }^{2,3}$ and Aleksei Krasnov ${ }^{1}$

Address: ${ }^{1}$ Nofima Akvaforsk Fiskeriforskning, P.O.Box 5010, Ås 1430, Norway, ${ }^{2}$ Institute of Marine Research, PO Box 1870, Nordnes, 5817 Bergen, Norway and ${ }^{3}$ Department of Biology, University of Bergen, Box 7800 N-5020 Bergen, Norway

Email: Stanko Skugor* - Stanko.Skugor@nofima.no; Kevin Alan Glover - kevin.glover@imr.no; Frank Nilsen - fni001@exchange.uib.no; Aleksei Krasnov - Aleksei.Krasnov@nofima.no

* Corresponding author

Published: 23 October 2008

BMC Genomics 2008, 9:498 doi:10.1/86/147|-2/64-9-498
Received: 27 May 2008

Accepted: 23 October 2008

This article is available from: http://www.biomedcentral.com//47/-2/64/9/498

(C) 2008 Skugor et al; licensee BioMed Central Ltd.

This is an Open Access article distributed under the terms of the Creative Commons Attribution License (http://creativecommons.org/licenses/by/2.0), which permits unrestricted use, distribution, and reproduction in any medium, provided the original work is properly cited.

\begin{abstract}
Background: The salmon louse (SL) is an ectoparasitic caligid crustacean infecting salmonid fishes in the marine environment. SL represents one of the major challenges for farming of salmonids, and veterinary intervention is necessary to combat infection. This study addressed gene expression responses of Atlantic salmon infected with SL, which may account for its high susceptibility.

Results: The effects of SL infection on gene expression in Atlantic salmon were studied throughout the infection period from copepodids at 3 days post infection (dpi) to adult lice (33 dpi). Gene expression was analyzed at three developmental stages in damaged and intact skin, spleen, head kidney and liver, using real-time qPCR and a salmonid cDNA microarray (SFA2). Rapid detection of parasites was indicated by the up-regulation of immunoglobulins in the spleen and head kidney and IL-I receptor type I, CD4, beta-2-microglobulin, IL-I2 $\beta, C D 8 \alpha$ and arginase I in the intact skin of infected fish. Most immune responses decreased at $22 \mathrm{dpi}$, however, a second activation was observed at $33 \mathrm{dpi}$. The observed pattern of gene expression in damaged skin suggested the development of inflammation with signs of Th2-like responses. Involvement of T cells in responses to SL was witnessed with up-regulation of CD4, CD8 $\alpha$ and programmed death ligand I. Signs of hyporesponsive immune cells were seen. Cellular stress was prevalent in damaged skin as seen by highly significant up-regulation of heat shock proteins, other chaperones and mitochondrial proteins. Induction of the major components of extracellular matrix, TGF- $\beta$ and IL10 was observed only at the adult stage of SL. Taken together with up-regulation of matrix metalloproteinases (MMP), this classifies the wounds afflicted by SL as chronic. Overall, the gene expression changes suggest a combination of chronic stress, impaired healing and immunomodulation. Steady increase of MMP expression in all tissues except liver was a remarkable feature of SL infected fish.
\end{abstract}

Conclusion: SL infection in Atlantic salmon is associated with a rapid induction of mixed inflammatory responses, followed by a period of hyporesponsiveness and delayed healing of injuries. Persistent infection may lead to compromised host immunity and tissue self-destruction. 


\section{Introduction}

The salmon louse (SL), Lepeophtheirus salmonis, is a marine ectoparasitic caligid crustacean infecting wild and farmed salmonids of the genera Salmo, Salvelinus and Onchorhynchus [1]. The life cycle consists of two planktonic larval stages, an infectious stage where copepodites attach to a suitable host, 4 immobile chalimus stages where the louse is firmly attached to the host's skin or fins, then 2 freemoving pre-adult stages before the final adult stage $[1,2]$. Heavy infestations present one of the major problems faced in marine salmon aquaculture and the concomitant rise of epizootics in wild populations is causing much debate about the possible ecological impacts of farmed fish $[3,4]$.

Salmon lice feed on host mucous, skin tissue and blood. Juveniles usually cause only abrasive wounds on the host skin but nevertheless lead to systemic stress responses and modulations of the immune system and physiology (reviewed in $[1,5,6]$ ). Host susceptibility differs among the salmonid species [7-10]. Coho salmon (O. kisutch) successfully expels parasites during chalimii stages while Atlantic salmon ( $S$. salar) fails to initiate inflammation and shows no apparent tissue responses to the attached larvae $[8,11]$. The ability to expel parasites can be determined with hyperplastic and inflammatory responses in the epidermis and underlying dermal tissues [1] and references therein. Hyperinflammatory phenotype in the resistant coho salmon is manifested within a day post infection and is characterised by a rich neutrophil influx at the site of parasite attachment. The inflammatory infiltrate persists during the whole period of salmon lice development on coho salmon and is accompanied with the pronounced epithelial hyperplasia that in some cases completely encapsulates the parasite. Intraspecific comparisons revealed the association of an early regulation of pro-inflammatory interleukin (IL)- $1 \beta$, IL- 8 and tumour necrosis factor- $\alpha$ (TNF- $\alpha$ ) with the improved chalimus expulsion in resistant species, which was attributed to the exaggerated $\mathrm{T}$ helper 1-type (Th1) responses (normally targeting viruses and bacteria) [12].

To elucidate the factors that determine high susceptibility of Atlantic salmon to lice and to evaluate the side consequences of infestation we conducted gene expression analyses throughout the life cycle, from copepodids to pre adults. Samples of damaged and intact sites of skin and immune organs (spleen, head kidney and liver) were collected 3 days post infection (dpi), 22 dpi, and $33 \mathrm{dpi}$; these time-points corresponded to the key stages (respectively copepodids, chalimus III/IV, preadult females and males). Multiple gene expression profiling is especially efficient in studies of scantily investigated conditions that may involve interactions of multiple factors. We used a high density salmonid fish cDNA microarray (SFA2 or immunochip) designed specifically for studies of responses to stressors and pathogens. In comparison with previous version ([13,14], GEO GPL1212), the updated platform was substantially enriched in immune genes (see[15]; GEO GPL6154). Real-time qPCR analyses were performed to validate the microarray results and to expand studies by examination of genes that were not present on the platform.

\section{Results \\ Responses to salmon lice in skin}

Samples of intact skin were collected from the infected salmon within the whole study period, however, it was not possible to sample damaged skin before $22 \mathrm{dpi}$ (see Materials and Methods, Fig. 7). Microarray analyses were designed to contrast the direct and indirect responses of infection with SL. Comparison of infected and intact sites from the same fish (Fig. 1) subtracted systemic responses and revealed the direct effects of parasites. Microarray comparison of intact skin from challenged and control fish was conduced to evaluate the systemic responses, however, expression changes were small (data not shown). The qPCR analyses were performed for damaged and intact skin, using skin from uninfected fish as control (Fig. 2). Both methods revealed profound changes in gene expression post infection.

Microarray analyses found differential expression of a number of genes linked to immunity. Ca-dependent (Ctype) lectin receptor $B$ and lectin receptor $C$, which were up-regulated in SL damaged skin, can take part in a multitude of biological processes. They regulate cellular interactions, including migration and adhesion of antigen presenting cells with lymphocytes [16,17]. In mammals, different dendritic cell (DC) subsets and maturation stages display distinct C-type-lectin profiles, depending on the local microenvironment and pathogen products $[18,19]$. Matrix metalloproteinases (MMP) 9 and 13 are commonly quiescent at the healthy state and become activated post-injury. These enzymes, working in conjunction with tissue inhibitors of metalloproteinases (TIMPs) (Fig. 1) can be involved in a wide range of processes such as cleavage and activation of cytokines, release of cytokines and growth factors from extracellular matrix (ECM), and establishment of a gradient for migration of cells [20]. Additionally, MMPs play the key role in the remodelling and destruction of ECM [21]. Both MMP9 and MMP13 displayed similar expression profiles, characterized by opposite regulation in the intact and damaged sites (Fig. 1 and Fig. 2D). The CCAAT/enhancer-binding protein (C/ EBP) family of transcription factors are involved in positive and negative control of cell proliferation and differentiation and immune responses [22](Fig. 1 and Fig. 2H). High-mobility group box protein, a proinflammatory 


\begin{tabular}{|c|c|c|}
\hline Genes & $22 \mathrm{dpi}$ & $33 \mathrm{dpi}$ \\
\hline \multicolumn{3}{|c|}{ Immune response, apoptosis, regulation of gene expression } \\
\hline \multirow{7}{*}{$\begin{array}{l}\text { C type lectin receptor B } \\
\text { C type lectin receptor C } \\
\text { Matrix metalloproteinase } 9 \\
\text { Matrix metalloproteinase-13 } \\
\text { Tissue inhibitor of metalloproteinase } \\
\text { CCAAT/enhancer binding protein beta } \\
\text { High-mobility group box } 1\end{array}$} & 0.98 & 5.64 \\
\hline & 1.25 & 1.62 \\
\hline & 1.19 & 2.07 \\
\hline & 2.23 & 6.68 \\
\hline & 0.80 & 3.34 \\
\hline & 5.09 & 4.59 \\
\hline & 0.28 & 2.03 \\
\hline \multirow{2}{*}{$\begin{array}{l}\text { LECT2 neutrophil chemotactic factor } \\
\text { Annexin } \mathrm{A} 1-1\end{array}$} & 0.28 & 0.94 \\
\hline & 0.67 & 1.72 \\
\hline \multirow{2}{*}{$\begin{array}{l}\text { Complement component C8 beta chain } \\
\text { X-box binding protein } 1\end{array}$} & 0.82 & 1.34 \\
\hline & 2.28 & 1.32 \\
\hline \multirow{6}{*}{$\begin{array}{l}\text { Nonspecific cytotoxic cell receptor } \\
\text { Mitogen-activated protein kinase } 6 \\
\text { CD63 } \\
\text { B-cell translocation gene } 1-2 \\
\text { X-linked interleukin-1 receptor acces sory } \\
\text { Cofactor required for Sp1 activation, subunit }\end{array}$} & 2.69 & 1.19 \\
\hline & 1.02 & 1.07 \\
\hline & 0.87 & 0.84 \\
\hline & 0.80 & 0.79 \\
\hline & 0.74 & 0.32 \\
\hline & 0.56 & 1.01 \\
\hline Nucleophosmin 1 & 2.72 & 2.30 \\
\hline \multirow{3}{*}{$\begin{array}{l}\text { DNA-directed RNA polymerase II } 23 \mathrm{kDa} \text { po } \\
\text { Fibrillarin } \\
\text { Interleukin } 13 \text { receptor alpha-2 }\end{array}$} & 1.38 & 2.00 \\
\hline & 1.32 & 1.68 \\
\hline & -2.51 & -2.10 \\
\hline \multirow{3}{*}{$\begin{array}{l}\text { Quinone oxidoreductase } \\
\text { Beta-2-microglobulin-1 JB1 } \\
\text { beta-2 microglobulin-1 BA1 }\end{array}$} & -0.42 & -0.59 \\
\hline & -0.09 & -1.44 \\
\hline & -0.29 & -1.66 \\
\hline \multirow{2}{*}{$\begin{array}{l}\text { Sphingosine 1-phosphate receptor Edg-3 } \\
\text { Serine protease-like protein-1 }\end{array}$} & -0.82 & -1.84 \\
\hline & -0.46 & -1.16 \\
\hline \multirow{8}{*}{$\begin{array}{l}\text { Serine protease-like protein-1 } \\
\text { Deoxyribonuclease gamma precursor } \\
\text { Deoxyribonuclease I-like } \\
\text { G1/S-specific cyclin D2 } \\
\text { Cytochrome P450 } 27 \\
\text { All-trans-13,14-dihydroretinol saturase } \\
\text { TATA-binding protein as sociated factor 2N } \\
\text { Prostaglandine D synthase } \\
\text { 5-lipoxygenase activating protein }\end{array}$} & -0.48 & -1.05 \\
\hline & -0.32 & -2.02 \\
\hline & -0.60 & -1.34 \\
\hline & -1.21 & -0.61 \\
\hline & -0.59 & -0.86 \\
\hline & -0.89 & -1.53 \\
\hline & -0.32 & -3.53 \\
\hline & -0.71 & -0.10 \\
\hline \multicolumn{3}{|l|}{ Mitochondria, oxidative stress } \\
\hline \multirow{7}{*}{$\begin{array}{l}\text { ADP,ATP carrier protein } 3 \\
\text { ADP,ATP carrier protein T2 } \\
\text { ATP synthase beta chain-1 } \\
\text { Cytochrome c-1 } \\
\text { Glutathione peroxidase } \\
\text { Thioredoxin } \\
\text { Thioredoxin-like protein 4A }\end{array}$} & 1.06 & 0.41 \\
\hline & 0.91 & 1.23 \\
\hline & 0.90 & 0.30 \\
\hline & 1.84 & 1.28 \\
\hline & 0.82 & 1.62 \\
\hline & 0.54 & 3.45 \\
\hline & -0.66 & -4.85 \\
\hline
\end{tabular}

\begin{tabular}{|c|c|c|}
\hline Genes & $22 \mathrm{dpi}$ & $33 \mathrm{dpi}$ \\
\hline \multicolumn{3}{|l|}{ Protein folding, cellular stress } \\
\hline \multicolumn{3}{|l|}{ 14-3-3 B1-like } \\
\hline $\begin{array}{l}\text { 14-3-3C2 } \\
78 \mathrm{kDa} \text { glucose-regulated protein }\end{array}$ & 1.84 & 2.48 \\
\hline 78 kDa glucose-regulated protein & 3.08 & 0.92 \\
\hline \multirow{2}{*}{$\begin{array}{l}94 \text { kDa glucose-regulated protein } \\
\text { Heat shock } 60 \text { kDa protein }\end{array}$} & 1.04 & 0.98 \\
\hline & 1.55 & 1.66 \\
\hline Heat shock 70 kDa protein 1 & 0.88 & 0.86 \\
\hline Heat shock $70 \mathrm{kD}$ protein 9B & 1.93 & 0.54 \\
\hline $\begin{array}{l}\text { Heat shock } 70 \mathrm{kDa} \text { protein } 8 \\
\text { Heat shock coanate } 70 \mathrm{kDa} \text { protein }\end{array}$ & 0.81 & 0.93 \\
\hline \multirow{2}{*}{$\begin{array}{l}\text { Heat shock cognate } 70 \mathrm{kDa} \text { protein } \\
\text { Heat shock cognate } 71 \mathrm{kDa} \text { protein }\end{array}$} & 0.92 & 0.93 \\
\hline & 0.74 & 0.82 \\
\hline Heat shock protein HSP 90-beta-2 & 1.59 & 1.64 \\
\hline $\begin{array}{l}\text { T-complex protein 1, alpha subunit } \\
\text { T-complex protein 1, gamma subunit }\end{array}$ & 0.45 & 2.39 \\
\hline \multirow{2}{*}{$\begin{array}{l}\text { T-complex protein } 1 \text {, gamma subunit } \\
\text { T-complex protein } 1 \text {, subunit } 2\end{array}$} & 0.32 & 0.83 \\
\hline & 1.10 & 1.30 \\
\hline \multirow{2}{*}{\multicolumn{3}{|c|}{$\begin{array}{l}\text { T-complex protein } 1 \text {, subunit } 5 \\
\text { Cytoskeleton, extracellular proteins }\end{array}$}} \\
\hline & & \\
\hline $\begin{array}{l}\text { Myosin heavy chain cardiac } \\
\text { Myosin heavy chain skeletal }\end{array}$ & -0.38 & -3.69 \\
\hline \multirow{2}{*}{$\begin{array}{l}\text { Myosin heavy chain skeletal } \\
\text { Myosin light chain }\end{array}$} & 0.84 & -2.24 \\
\hline & 1.54 & -1.72 \\
\hline Parvalbumin alpha-2 & 0.44 & -1.09 \\
\hline Reticulum calcium ATPase & 1.06 & -1.71 \\
\hline Actin alpha skeletal & 1.62 & 0.63 \\
\hline Actin, cytoplasmic & 1.48 & 1.88 \\
\hline \multirow{2}{*}{$\begin{array}{l}\text { Tropomyosin alpha } 3 \text { chain- } 3 \\
\text { Vacuolar ATP synthase } 16 \mathrm{kDa}\end{array}$} & 1.54 & 0.35 \\
\hline & 1.19 & 1.71 \\
\hline $\begin{array}{l}\text { Calpactin I light chain } \\
\text { Coronin-1B }\end{array}$ & 0.30 & 1.30 \\
\hline Coronin-1B & 0.94 & 1.25 \\
\hline \multirow{2}{*}{$\begin{array}{l}\text { PDZ and LIM domain protein } 1 \\
\text { Profilin-1 }\end{array}$} & 0.89 & 0.99 \\
\hline & 0.69 & 0.84 \\
\hline \multirow{2}{*}{$\begin{array}{l}\text { Cofilin, muscle isoform } \\
\text { ARP2/3 complex } 34 \mathrm{kDa} \text { subunit }\end{array}$} & 0.91 & 0.70 \\
\hline & 0.75 & 0.71 \\
\hline Cytokeratin 8 & 0.70 & 1.01 \\
\hline Tubulin alpha-3 chain & 0.91 & 0.96 \\
\hline Keratin, type II cytoskeletal 8 & 0.71 & 0.92 \\
\hline Tubulin alpha-ubiquitous chain & 0.77 & 0.91 \\
\hline Transgelin & 0.69 & 0.75 \\
\hline Calmodulin-1 & 0.87 & 0.57 \\
\hline Cathepsin B & 0.79 & 1.32 \\
\hline Cathepsin S & 1.05 & 1.13 \\
\hline Alpha 2 type I collagen-1 & NS & -3.04 \\
\hline Collagen alpha $1(\mathrm{~V})$ chain & 0.98 & -2.58 \\
\hline Collagen a3(I)-2 & 0.26 & -2.12 \\
\hline Collagen alpha 1 (I) chain-1 & 0.08 & -2.08 \\
\hline Collagen a3(I)-1 & 0.23 & -1.66 \\
\hline Hyaluronan and proteoglycan link protein & -0.23 & -0.89 \\
\hline
\end{tabular}

\section{Figure I}

Microarray comparison of gene expression in damaged and intact skin of SL infected fish, examples of differentially expressed genes. Pooled samples were analysed, data are log-ER (expression ratios). Significantly up- and down-regulated genes ( $p<0.0$ I, t-test, I 2 spot replicates per gene) are highlighted with red and green scales, NS means not significant.

cytokine with DNA binding properties [23] was up-regulated 33 dpi (Fig 1).

Down-regulation of a decoy receptor IL-13 receptor alpha2 (IL13R $\alpha 2$ ) implied induction of the IL-4/IL-13 axis [24] and possible polarization towards the Thelper 2-type (Th2) immune response, a typical response against parasites. The Thelper cells (Th) that differentiate into the Th2 subset are characterised by their ability to suppress development of the IL-12 producing Th1 subset [25]. There- 

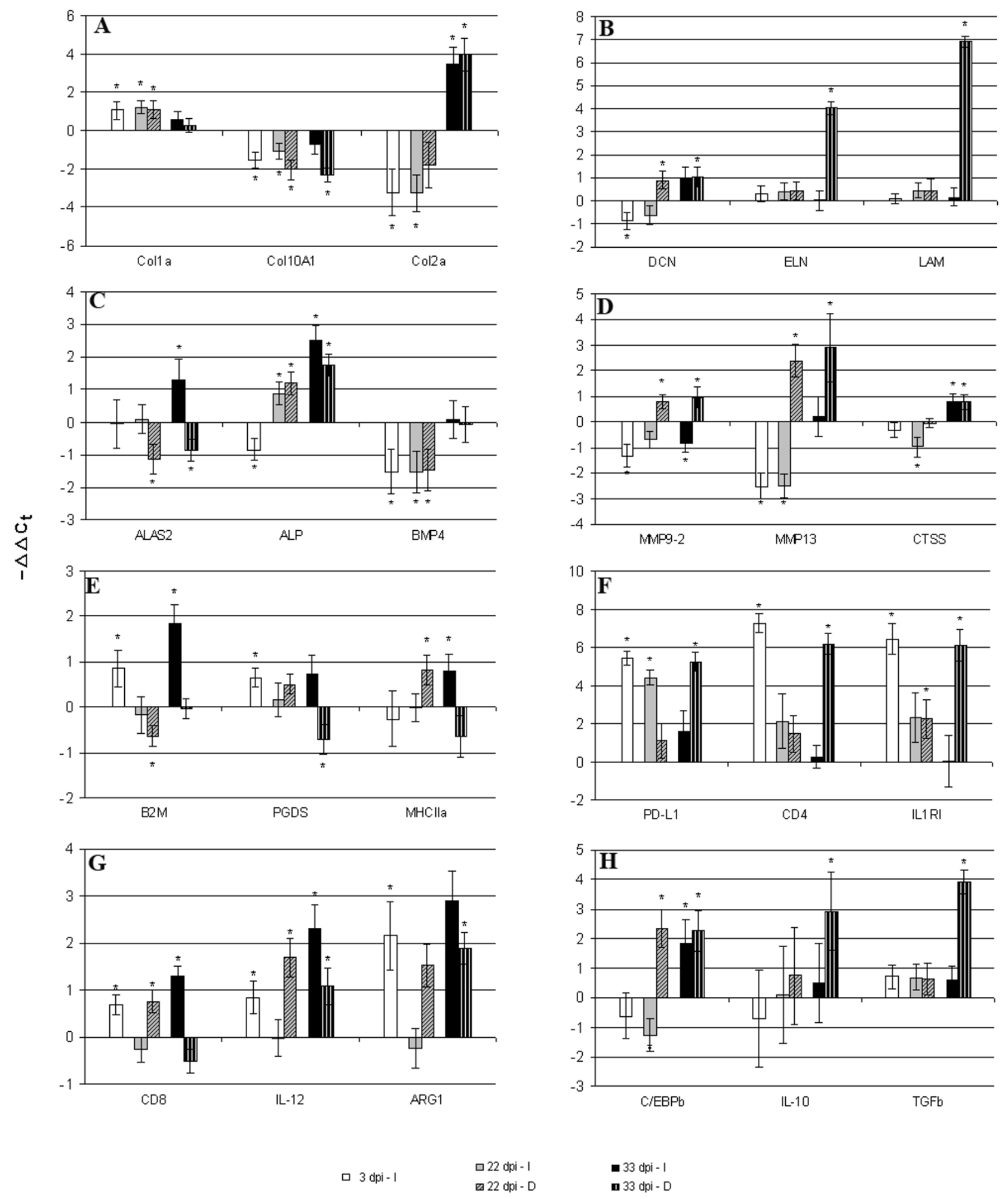

Figure 2 (see legend on next page) 
Figure 2 (see previous page)

Gene expression in skin analyzed with qPCR (individual samples). Data are $-\Delta \Delta C t \pm S D(n=6)$. A. collagen $(C O L)$ genes: COLIa, COL2a and COLIOa B. components of the extracellular matrix (ECM): decorin (DCN), elastin (ELN) and laminin (LMN) C. 5-aminolevulinate synthase (ALAS2), alkaline phosphatase (ALP) and regulatory bone morphogenic protein (BMP4) D. proteases involved in ECM remodelling, matrix metalloproteinases (MMP) 9 and I3 and in antigen presentation, cathepsin S (CTSS) E. beta-2-microglobulin-2 JBI (B2M), a component of the major histocompatibility complex (MHC) class I; $\mathrm{MHC}$ class II $\alpha$ chain (MHClla) and regulator of inflammation prostaglandine D synthase (PGDS) F. T cell-inhibitory programmed death ligand I (PD-LI), CD4, marker of T cells and IL-I receptor type I (ILIRI), transducer of pro-inflammatory signals G. CD8 $\alpha$, expressed on cytotoxic T cells; IL-I2 $\beta$, produced in ThI settings and ARGI, marker of the Th2 response H. CCAAT/enhancer-binding protein $\beta(\mathrm{C} / \mathrm{EBPb})$ involved in the control of cell proliferation and differentiation; regulatory cytokines IL- 10 and transforming growth factor- $\beta$ (TGF- $\beta$ ). Significant difference from uninfected control (t-test, $P<0.05)$ is indicated with *. I-intact skin of infected fish, D-skin damaged by sea lice

fore, we included in qPCR analyses the key genes that could give information on the type and dynamics of T cell responses throughout the study period (Fig. 2E, F, G, and $2 \mathrm{H})$. Marked increase of CD4 transcripts $3 \mathrm{dpi}$ at intact sites supports a rapid infiltration of $\mathrm{T}$ cells into the skin after the exposure to copepodids (Fig. 2F). High expression of CD 4 at injured sites 33 dpi indicates a second wave of $\mathrm{T}$ cell migration from lymphoid organs or an increased proliferation in the periphery. CD4+ Th cells are essential intermediaries of the adaptive immune system, which instruct innate effector cells and amplify their responses mainly through the secretion of specific cytokines. IL-1 receptor type 1 (IL1RI) transduces signals from proinflammatory cytokines IL-1 $\beta$ and IL $1 \alpha$ and can serve as a marker of a newly described highly inflammatory effector Th subset, Th17 [26]. The IL1RI expression profile was similar to that of CD4 (Fig. 2F). IL1RI was highly responsive to SL induced damage whereas its expression steadily declined in the intact sites after the initial increase $3 \mathrm{dpi}$. IL-10 can down regulate inflammatory Th responses via a regulatory CD4+ subset, Treg [27]. Both IL-10 and TGF- $\beta$ are pleiotropic cytokines, which are generally regarded as anti-inflammatory. We observed synchronous up-regulation of IL-10 and TGF- $\beta$ at 33 dpi (Fig. 2H). Possible differentiation of Th1 was indicated with changes of the transcript levels of IL-12 $\beta$ and beta-2-microglobulin-2 JB1 (B2M), a component of the major histocompatibility complex (MHC) class I (Fig. 2G, E). B2M was down-regulated $22 \mathrm{dpi}$ and interestingly, similar changes were observed in skin of carp infected with ectoparasite Ichthyophthirius multifiliis [28]. Changes of CD8 $\alpha$ suggested involvement of cytotoxic T cells (Fig. 2G). Arginase 1 (ARG1), a typical marker of alternatively activated macrophages (M2), central downstream effector cell of the Th2 response, implied the pronounced activation of M2 and their rapid recruitment both at the onset and at the end of infection (Fig. 2G). Activation of T cell-related genes $3 \mathrm{dpi}$ was followed with decline $22 \mathrm{dpi}$ and increase at $33 \mathrm{dpi}$ in intact skin (Fig. 2F, G). Sarcoplasmic/endoplasmic reticulum calcium ATPase involved in calcium sequestration was up-regulated $22 \mathrm{dpi}$ in injured areas and then down regulated 33 dpi (Fig. 1). A similar expression pattern was seen in several genes involved in calcium signaling and muscle contraction, including calcium-binding protein parvalbumin $\alpha 2$ and several myosin genes (Fig. 1).

Regulation of a number of genes with known anti-inflammatory actions was observed. Annexins were consistently up-regulated at the damaged sites (Fig. 1) [29]. Increase of prostaglandine D synthase (PGDS) expression 3 dpi was followed with down-regulation $33 \mathrm{dpi}$ at the sites of SL attachment (Fig. 1 and Fig. 2E). PGDS is the key enzyme involved in the synthesis of $\mathrm{PGD}_{2}$, which is further metabolized to $15-\mathrm{d}_{-} \mathrm{PG} \mathrm{J}_{2}$, a potent anti-inflammatory mediator [30]. It can inhibit the production of iNOS, TNF- $\alpha$ and IL$1 \beta$ in macrophages through the inhibition of MAP kinases, nuclear factor kappaB (NFkB) or IkB kinase [31,32]. 15-d-PGJ2 mediates the inhibition of proliferative responses of T cells and induces apoptosis of T cells by a PPAR- $\gamma$-dependent mechanism [33].

Accumulation of misfolded proteins in endoplasmic reticulum lumen activates a set of intracellular signalling steps collectively called the unfolded protein response (UPR). UPR is induced by a variety of insults, including nutrient and oxygen deprivation, pathogen infections, changes in redox status and intralumenal calcium (reviewed in [34]). Microarray analyses showed highly significant induction of mitochondrial proteins involved in biosynthesis and transport of ATP, heat shock proteins, $94 \mathrm{kDa}$ glucose-regulated protein (GRP94), $78 \mathrm{kDa}$ glucose regulated protein (GRP78), and X-box binding protein 1 (XBP-1) indicating unfolded protein response (UPR), typical of wounded tissue (Fig. 1).

As expected, massive changes in genes for proteins of ECM took place and they were substantially greater in the damaged sites (Fig. 1 and Fig. 2A, B). In addition to MMPs, several lysosomal proteases, cathepsins were regulated, which was in line with the degradation of tissue (Fig. 1 and Fig. 2D). Secreted cathepsin S (CTSS) is an elastolytic cysteine protease capable of degrading ECM components. 
We observed down-regulation of several types of collagens and up-regulation of elastin and laminin in the damaged sites and these changes increased markedly at the late stage of SL development (Fig. 1 and Fig 2A, B). Gene expression changes that can be relevant to remodelling of ECM were not only observed in infected sites. Down-regulation of decorin (DCN) was found in intact skin 3 dpi and 22 dpi (Fig. 2B). Rapid changes were seen in the bone morphogenetic protein (BMP4), which was markedly suppressed until 33 dpi in both intact and injured sites (Fig. 2C). The enzymes involved in modification of extracellular matrix also showed rapid responses (Fig. 2D). Increase of alkaline phosphatase (ALP) activity was reported in mucus of SL infected Atlantic salmon [35] and in regenerated scales of a common goby [36]. In the present study, early decrease of ALP expression at the intact sites was followed with the up-regulation in all areas (Fig. 2C).

\section{Responses to salmon lice in the head kidney, liver and spleen}

The gene expression changes in the intact sites of skin suggested rapid systemic responses to parasites. This was supported by the results of analyses in the head kidney, spleen and liver (Fig. 3 and Fig. 4). These organs were included in the study due to their essential roles in immunity. Rapid change was seen in a group of immunoglobulin (IG) like genes, which then returned toward control levels in the head kidney (Fig. 3B). Early increase of the expression of these genes in the spleen declined during chalimus developmental stages, with subsequent return to a similar level to initial by day 33. Changes of MMPs (delayed increase in the head kidney and spleen first noticed at $22 \mathrm{dpi}$ ) were one of the most remarkable features of the infected fish (Fig. 3A and Fig. 4A). In our earlier studies, similar MMP profiles were observed in rainbow trout challenged with handling stress [14]. Differential expression of B2M was seen in all studied tissues of SL-infected fish and only in the liver these genes were up-regulated (Fig. 3A). Quinone oxidoreductase and alltrans-13,14-dihydroretinol saturase were progressively down-regulated in the liver while opposite was seen for quinone oxidoreductase in the head kidney and for alltrans-13,14-dihydroretinol saturase in the spleen (Fig $3 \mathrm{~A})$. Adenosine deaminase is a regulator of inflammation $[37,38]$, which was down-regulated in liver $22 \mathrm{dpi}$, while it had a peak in expression at the same stage of infection in the head kidney and spleen (Fig. 3A). C-type mannose binding lectin (MBL1) was up-regulated in liver but only 3 dpi and 33 dpi (Fig. 3A and Fig. 4B). MBL recognises carbohydrates on both foreign organisms and damaged cells and cellular debris and then initiates their removal and local inflammatory responses. The 5-lipoxygenase activating protein was markedly activated in head kidney at all stages but only $33 \mathrm{dpi}$ in spleen (Fig. 3A). This protein is required for the production of leukotrienes, best known for their potent chemotactic and leukocyte-activating effects $[39,40]$. CXC chemokine receptor (CXCR4) has a potent chemotactic activity for lymphocytes and was shown to inhibit haematopoietic stem cell proliferation [41]. In the present study, up-regulation of CXCR4 in spleen 22 dpi was observed (Fig. 4A). A suit of other chemokines with potential roles in recruitment and activation were regulated in internal organs (CC chemokine SCYA110-1, CC chemokine SCYA110-2, leukocyte cellderived chemotaxin 2 and macrophage migration inhibitory factor-like) (Fig. 3A).

Co-ordinated changes were seen in the genes involved in metabolism of iron and erythropoiesis. In head kidney and spleen this group was down-regulated within whole study period while in liver, initial decrease was followed with the gradual elevation. Selected representatives for qPCR analyses in spleen were haemoglobin beta chain (HBB) and erythroid-specific 5-aminolevulinate synthase (ALAS2) (Fig. 4A) and heme oxygenase 1 (HMOX1) and HBB in liver (Fig. 4B).

\section{Discussion}

Results of this study represent a significant contribution into the understanding of the underlying physiological basis for the high susceptibility of Atlantic salmon to salmon lice and the side effects caused by the infection with this parasite. The ability to reject parasites can be determined with inflammation and healing of wounds, and here, we observed expression changes of genes involved in these processes.

\section{ECM and wound healing}

The pathology of Atlantic salmon infected by high numbers of lice is characterised by gross lesions, vast areas of eroded skin on the head and back, necrotic tissue and subepidermal haemorrhaging at margins of lesions (reviewed in [1]). Because of the danger of osmotic shock in aqueous environment, any break in the fish skin must be rapidly repaired. The initial hemostatic event upon breaching of epidermis provides the provisional fibrin-fibronectin wound matrix, which is a framework for cell adhesion, migration, and repair [42]. Maintaining sufficiently high levels of plasma fibronectin, produced in the liver, plays an important role in wound healing [43]. Fibronectin was down-regulated in liver of Atlantic salmon already $3 \mathrm{dpi}$ and continued until $33 \mathrm{dpi}$, suggesting limited wound healing ability in the afflicted skin (Fig. 3A). Fibronectin is a large adhesive glycoprotein which interacts with cells and transmits signals primarily through integrin receptors expressed on a variety of epidermal cells including keratinocytes, endothelial cells and fibroblasts, allowing them to interweave with the fibrin clot in the wound space $[44,45]$. In a fish scale-skin culture system, dermal sub- 
A

\begin{tabular}{|c|c|c|c|c|c|c|c|c|c|}
\hline Genes & HK-3dpi & HK-22dpi & HK-33dpi & L-3dpi & L-22dpi & L-33dpi & S-3dpi & S-22dpi & S-33dpi \\
\hline \multirow{5}{*}{$\begin{array}{l}\text { Matrix metalloproteinase-13 } \\
\text { Matrix metalloproteinase-9 } \\
\text { Tissue inhibitor of metalloproteinase } \\
\text { beta-2 microglobulin-1 BA1 } \\
\text { Beta-2-microglobulin-2 JB1 }\end{array}$} & 0.42 & 0.76 & 0.24 & NS & NS & 0.36 & 0.16 & 1.00 & 0.24 \\
\hline & -0.51 & 0.65 & 0.54 & -0.13 & NS & NS & NS & 0.94 & 1.86 \\
\hline & -0.55 & 0.50 & 0.55 & NS & NS & -0.36 & NS & 0.68 & 2.10 \\
\hline & 0.31 & -1.09 & -1.13 & 0.44 & -0.47 & 1.54 & NS & -0.49 & -0.55 \\
\hline & 0.31 & -1.11 & -0.64 & NS & NS & NS & NS & -0.58 & -0.55 \\
\hline \multirow{3}{*}{$\begin{array}{l}\text { All-trans-13,14-dihydroretinol saturase } \\
\text { 5-lipoxygenase activating protein } \\
\text { Quinone oxidoreductase }\end{array}$} & 0.94 & NS & NS & 0.82 & 0.73 & 0.21 & 1.86 & 1.59 & 1.57 \\
\hline & 0.68 & 0.77 & 0.51 & NS & NS & 0.33 & 0.53 & NS & 0.53 \\
\hline & -0.64 & 0.31 & NS & NS & -0.79 & -0.96 & -0.59 & NS & NS \\
\hline \multirow{2}{*}{$\begin{array}{l}\text { Adenosine deaminase } 3 \\
\text { Annexin A1-1 }\end{array}$} & -0.63 & 0.33 & 0.28 & -0.32 & -0.91 & -1.10 & -1.12 & 0.56 & 0.32 \\
\hline & -0.67 & NS & 0.37 & NS & NS & NS & NS & -0.52 & 0.67 \\
\hline \multirow{3}{*}{$\begin{array}{l}\text { C-type mannose-binding lectin } \\
\text { Macrophage migration inhibitory factor } \\
\text { CC chemokine SCYA } 110-1\end{array}$} & NS & NS & NS & 1.78 & NS & 4.28 & NS & NS & -0.31 \\
\hline & 2.05 & -0.90 & NS & NS & NS & NS & NS & NS & NS \\
\hline & NS & NS & 0.36 & NS & NS & -0.91 & NS & 0.88 & 0.67 \\
\hline \multirow{3}{*}{$\begin{array}{l}\text { CC chemokine SCYA110-2 } \\
\text { Leukocyte cell-derived chemotaxin } \\
\text { Chemokine receptor CXCR4 }\end{array}$} & -0.96 & NS & 1.85 & -0.19 & NS & -0.41 & -0.56 & 0.72 & 3.14 \\
\hline & NS & -0.42 & NS & -0.23 & -0.78 & 0.85 & 0.23 & -0.15 & 0.09 \\
\hline & NS & NS & NS & NS & NS & NS & 0.10 & 1.32 & 0.46 \\
\hline \multirow{2}{*}{$\begin{array}{l}\text { Fibronectin precursor } \\
\text { Cathepsin B-2 }\end{array}$} & NS & NS & NS & -0.44 & -0.49 & -1.41 & NS & NS & NS \\
\hline & -0.19 & -0.52 & NS & NS & NS & 0.56 & 0.22 & -0.10 & 0.68 \\
\hline \multirow{4}{*}{$\begin{array}{l}\text { Cathepsin S } \\
\text { Interferon regulatory factor } 1-1 \\
\text { Liver-expressed antimicrobial peptide } 2 B \\
\text { Lysozyme C precursor }\end{array}$} & 0.55 & 0.31 & 0.13 & NS & NS & NS & 0.17 & -0.27 & NS \\
\hline & NS & -0.29 & NS & NS & NS & NS & 0.43 & -0.46 & NS \\
\hline & NS & NS & NS & 0.94 & 0.36 & 0.90 & NS & NS & NS \\
\hline & -0.16 & -0.89 & -0.86 & -0.99 & NS & NS & NS & -0.51 & -1.36 \\
\hline \multirow{2}{*}{$\begin{array}{l}\text { All-trans-13,14-dihydroretinol saturase } \\
\text { ATP-binding cassette D3 }\end{array}$} & -0.04 & NS & NS & -1.17 & -0.27 & 0.30 & -0.60 & 0.54 & 0.77 \\
\hline & NS & NS & NS & NS & NS & 0.51 & NS & 0.89 & 1.98 \\
\hline \multirow{4}{*}{$\begin{array}{l}\text { ATP-binding cassette transporter } 1 \\
\text { ATP-binding cassette, sub-family F } \\
\text { 5-aminolevulinate synthase } \\
\text { Integrin beta-1-binding protein }\end{array}$} & NS & NS & NS & NS & NS & -0.96 & NS & 0.60 & 0.54 \\
\hline & NS & NS & NS & NS & 0.50 & NS & -0.62 & -0.90 & -0.71 \\
\hline & 0.24 & -0.41 & -0.32 & -1.15 & NS & NS & -0.52 & -0.79 & -1.07 \\
\hline & NS & -0.44 & -0.31 & NS & 0.37 & NS & -0.97 & -0.98 & -0.65 \\
\hline
\end{tabular}

B

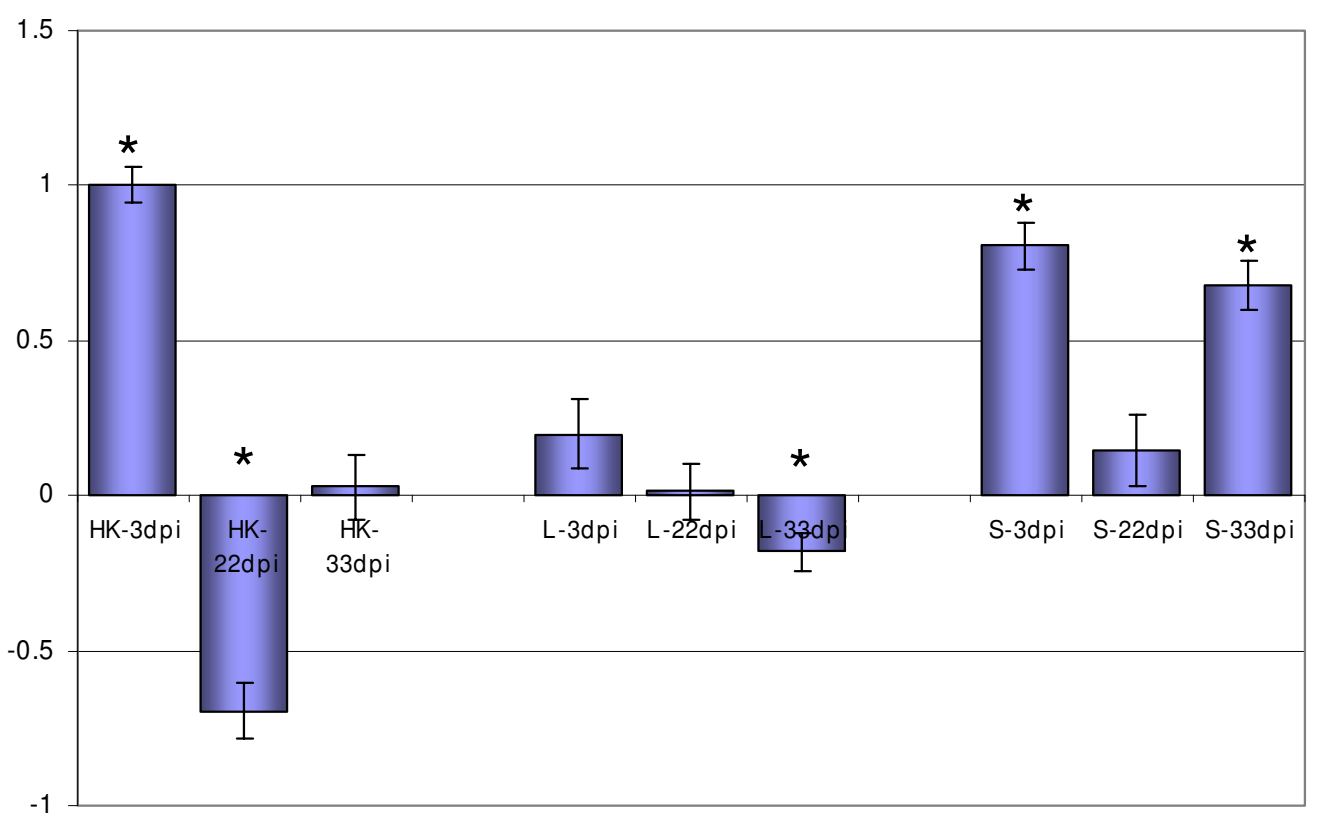

\section{Figure 3}

Microarray analyses of gene expression in head kidney (HK), liver (L) and spleen (SP). Pooled samples were analysed using uninfected fish as a common reference. A - log-expression ratios. Significantly up- and down-regulated genes ( $p<$ 0.05 , t-test, 12 spot replicates per gene) are highlighted with red and green scales, NS is not significant. B: mean expression profiles of nine immunoglobulins designated by the Unigene clusters and most similar mammalian genes: Omy 939I (Ig kappa chain V-III region VG), Omy 416 (Ig kappa chain V-IV region JI), Omy 233 I2 (Ig kappa chain V-IV region BI7-I), Omy 939I (Ig kappa chain C region), Omy 3009 I (Ig kappa chain V-IV region Len), Ssa 709 (Ig kappa chain V-IV region BI7-2), Ssa 78 (Ig heavy chain V-III region HIL), Omy I 287 (Ig mu heavy chain disease protein), Ssa 709 (Ig kappa chain V-I region WEA) Data are mean log-expression ratios $\pm S E$, significant differences from zero $(p<0.05)$ are indicated with *. 


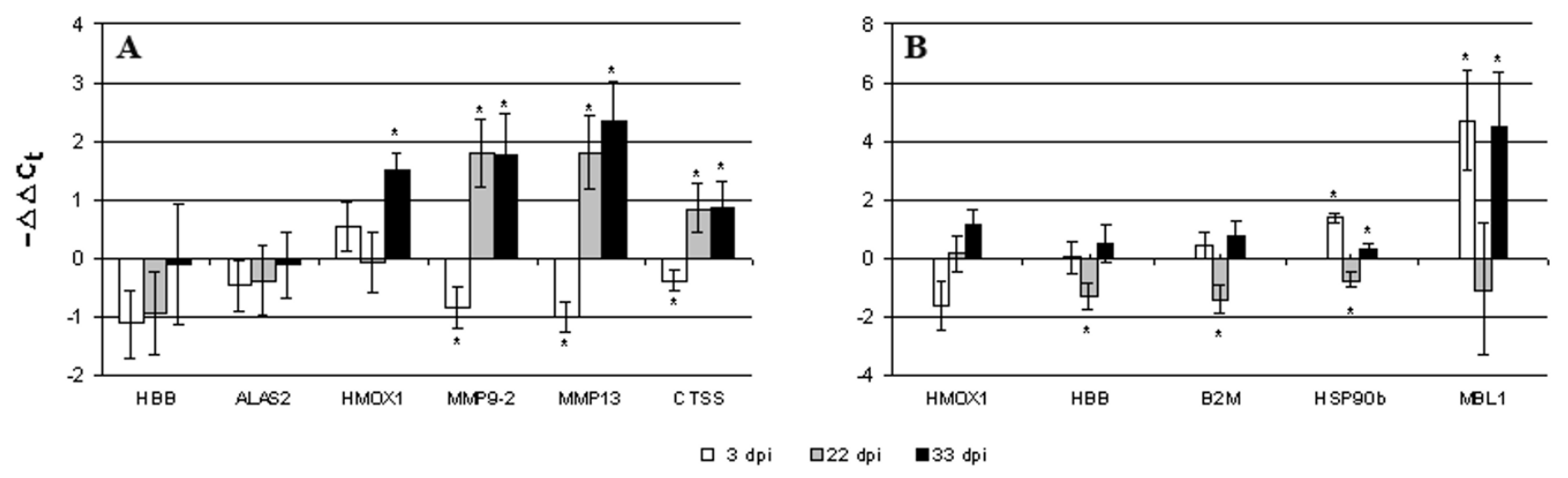

\begin{abstract}
Figure 4
Gene expression in spleen(A)and liver (B) analyzed with qPCR (individual samples). Data are $-\Delta \Delta C t \pm$ SD $(n=6)$. Significant difference from uninfected control ( $t$-test, $p<0.05)$ is indicated with *. A: spleen. Haemoglobin beta $(H B B)$ and $5-$ aminolevulinate synthase (ALAS2) were selected for $\mathrm{qPCR}$ analyses as the representatives of genes involved in erythropoiesis and metabolism of iron. Two metalloproteinases (MMP) 9 and I 3 engage in ECM remodelling and cathepsin S (CTSS) may indicate activation of the ThI-related adaptive immunity B: liver. Genes selected for qPCR analyses: heme oxygenase I (HMOXI) and HBB, involved in iron metabolism; beta-2-microglobulin-2 JBI (B2M), an indicator of ThI responses; heat shock protein 90 $\beta$ (HSP90b), implied in cellular stresses; C-type mannose binding lectin (MBLI), receptor possibly involved in the recognition of SL-derived antigens. Significant difference from uninfected control (t-test, $p<0.05$ ) is indicated with *.
\end{abstract}

strates such as fibronectin and type I collagen were able to initiate migration of keratinocytes and epidermal outgrowth even in the absence of growth factors [46]. In the present study, expression profiles of genes encoding ECM components were also similar to profiles characteristic for slowly repairing injuries [47-49]. This included down-regulation of several collagens at the end of experiment. A slight but consistent up-regulation of COL1a was detected by qPCR, however, COL10a was stably down-regulated as well as COL2a at $3 \mathrm{dpi}$ and $22 \mathrm{dpi}$. A relatively low induction of decorin, a regulator of assembly of collagen fibrils $[50,51]$ and TGF- $\beta$ activity $[52,53]$, was seen 22 dpi and similar changes were observed in ALP. However marked up-regulation of major ECM proteins elastin and laminin was seen only $33 \mathrm{dpi}$ as well as induction of COL2a. Noteworthy, slow reparation of ECM was in parallel with stable up-regulation of MMP9 and MMP13 in the damaged sites, whose excessive activity may contribute to the development of chronic wounds [54].

Delayed wound healing could be accounted for by the insufficient expression of several regulatory proteins. Increase of TGF- $\beta$, an essential stimulator required for ECM development [55], was seen not earlier than 33 dpi. Actions of TGF- $\beta$, which is released from platelets and macrophages immediately after injury, largely depend on the presence of fibronectin and other ECM components [53] and vice versa. It attracts neutrophils, macrophages, and fibroblasts, which in turn release more TGF- $\beta$. Relatively modest changes in matrix composition were shown to have major effects on cell responses and growth [56], including self-renewal [57]. We studied the expression of a developmentally important gene, BMP4, another TGF superfamily member, which is known to be up-regulated in undifferentiated stem-like cells [58] and to play an important role in skin homeostasis [59]. This gene was markedly down-regulated until 22 dpi. Collectively, these gene expression profiles of skin ECM and MMPs classify the wounds afflicted by SL as chronic, due to the significantly protracted duration and deregulation of events in the healing cascade. Together with opposite expression changes of several genes in the intact and damaged sites (MMPs, C/EBPb) this could indicate a modulatory activity of SL and/or constant damage inflicted by the growing parasites. The ability of SL to reduce the protective responses has been reported by several groups. Firth et al. (2000) [60] characterised low molecular proteases (LMW) secreted by $L$. salmonis onto the surface of the fish as trypsins, which are known to be used by many parasites for invasion and to suppress immune responses in their hosts [61]. Fast et al. [11] correlated the reduced respiratory burst and phagocytosis in macrophages of infected Atlantic salmon and rainbow trout with the appearance of LMW bands in the mucus.

\section{Inflammatory responses}

The rate of wound healing and the ability to reject parasites could also be explained by the characteristics of inflammatory responses to SL. Inflammation is regarded as a two-edged sword since destructive alterations are 
closely associated with the subsequent reparation of damaged tissues and often involve the same or closely related molecular mechanisms and cellular elements. Hence, suppression of inflammation may result in chronicity. In SL infected coho salmon, tissues develop pronounced epidermal hyperplasia at the sites of attachment, which is accompanied with abundant cellular infiltration within the dermis beneath chalimii $[1,8]$. Inflammatory infiltrate consists mostly of neutrophils. Cellular debris and phagocyte neutrophils are abound at the early phases of infection whereas macrophages and a small number of lymphocytes appear later. Collectively, the findings in these studies are in line with our results showing restricted tissue inflammatory changes at both copepodid and chalimus stages. Early up-regulation of immunoglobulinlike genes in the head kidney and spleen, in addition to a panel of immune genes in the intact areas of skin, indicated a rapid activation of the systemic antiparasitic responses. In SL infected skin, up-regulation of Sp1 cofactor, a partner of NFkB [62], provided indirect evidence for possible activation of the NFkB pathway. An inflammatory state could also explain the decreased expression of quinone oxidoreductase in SL skin $33 \mathrm{dpi}$, as was similarly observed in mammalian cells [63]. However, the input of NFkB pathway in responses to SL was relativley low. At low level of NFkB activation, T cells develop an anergic state through Ca2+ signalling [64]. In this respect, it is noteworthy to mention that SL infection induced a number of $\mathrm{Ca} 2+$ regulatory genes, e.g. calcineurin, calmodulin and calpactain I light chain (Fig. 1B).

Restricted inflammatory responses in SL damaged skin were in parallel with massive up-regulation of chaperones indicative of the induction of UPR. In addition, increased levels of genes regulating mitochondrial proteins were observed. This has been previously observed in relation to responses to handling stress [14] and acute toxicity $[13,65]$ in rainbow trout. Such opposite regulation of stress and immune responses is well known. Cortisol, the most common marker of stress in fish is widely used for anti-inflammatory therapy. Increased levels of cortisol that were reported in lice infected salmon $[12,35,66]$ can at least partly account for the lack of strong inflammation. Steady increase of MMPs in all organs except liver was a remarkable feature of SL infected salmon. In salmonid fish these genes are up-regulated with both stress and inflammatory agents $[14,67]$. Prolonged stress, infection and combination of these two can result in chronic degradation of ECM.

\section{What immune cells can be involved in responses to SL?}

Microarray analyses revealed signs of inflammation but did not indicate which immune cells could have taken part in responses to SL. To address this, a set of markers was included in the GPCR analyses. ARG1, a marker of alternatively activated macrophages (M2) [68] with an important role in tissue remodelling and wound healing [69], was up-regulated 3 and 33 dpi but down-regulated $22 \mathrm{dpi}$ at the intact sites. In contrast to classically activated macrophages (M1), M2 are induced by Th2 cytokines IL4 and IL-13, that are prevalent at parasitic infections and in wound settings [70,71]. The maintenance of $\mathrm{M} 2$ requires the adaptive arm of the immune system [72]. Therefore, decreased ARG1 expression 22 dpi suggested the possibility of insufficient signaling from the responsible T cell subset (Th2) at this stage.

Responses to parasites are often described in terms of Th1/ Th2 dichotomy but recent studies have shown that hostpathogen interactions are more complex. A novel T cell effector subset Th17, characterised by the production of IL-17 was identified as well as a regulatory T cell subset (Treg), its signature cytokines being inhibitory IL-10 and/ or TGF- $\beta$ [73]. In mammals Th1, Th2 and Th17 reciprocally regulate the development and function of each other, while Treg cells suppress all three subsets $[74,75]$. The regulatory cytokines control inflammation and thus protect against immunopathology, but, in so doing, they reduce the effectiveness of immune mechanisms responsible for the expulsion of the parasites. Th2-dependent immune effector mechanisms are diverse and include fibroblast recruitment to the damaged tissue and collagen production, smooth muscle hypercontractivity and accelerated epithelial cell turnover $[70,71,76]$. Numerous studies of fish-parasite interactions described physiological responses, typically induced in a Th2 setting, e.g. increased mucus production and goblet cell hyperplasia in Gyrodactilus and SL infection models $[1,5,77]$.

It is becoming increasingly evident that a superimposition of polarized response profiles in parasitic infections is the norm rather than the exception $[75,78]$. Concurrent regulation of markers of opposing immune responses in this study adds to this notion, e.g. early $\mathrm{T}$ cell response occurred in both the CD4+ and CD8+ T cell compartment (Fig. 2F, G). We visualized the map of immune responses which can accommodate for any particular combination of activated T cell responses (Fig. 5). In this map, each of the four major $\mathrm{T}$ cell-mediated responses can overlap with any other one and more than a combination of two is possible. Although Th1, Th2, Th17 and Treg are regulated with the lineage-specific sets of cytokines and respond to different targets, they can coexist in combinations. Th1 and Th2 responses can overlap with anti-inflammatory Treg or, quite the opposite, with the Th17 responses.

A specific set of innate effector cells is summoned by each of these T cell subsets. The newly described Th17 developmental pathway is characterised by the rapid neutrophilia [79]. The Th17 is thought to be an ancient lineage highly 


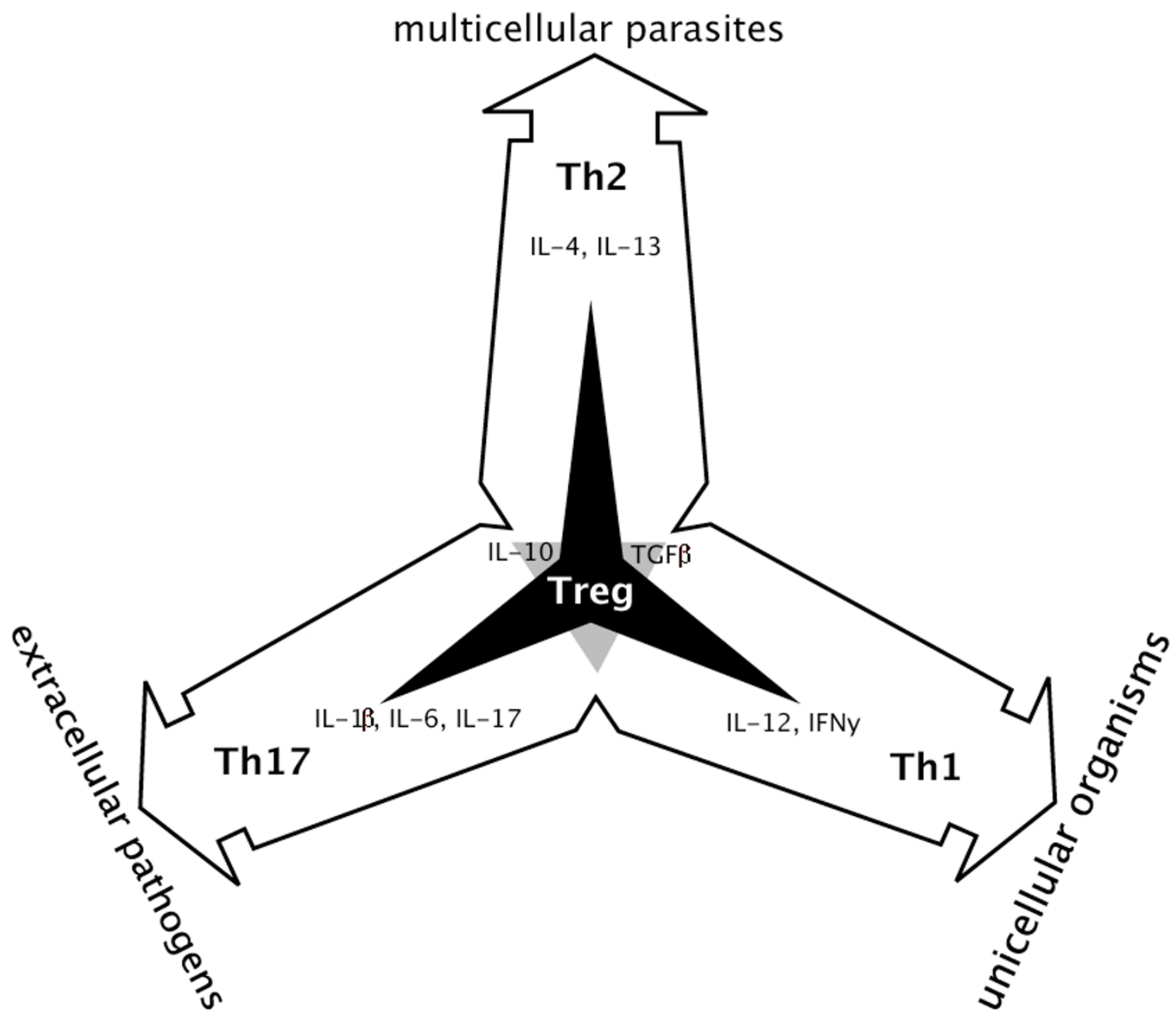

Figure 5

A map of T cell-mediated responses to pathogens. Three effector subsets, ThI, Th2, Th I7, and the regulatory Treg are characterized by distinct cytokine profiles [73]. All three pro-inflammatory subsets reciprocally antagonize each other as indicated with a grey triangle in the centre where they were shown to overlap. Treg cells, represented with a black three-pointed star superimposed at the centre of the figure, inhibit all three Th subsets, thus preventing excessive inflammatory responses. $T$ cell-mediated responses represent combined immune responses, which include both innate and adaptive components. Immune response to most bacterial and viral pathogens is generally pro-inflammatory. The ThI cells secrete interferon $\gamma$ (IFN $\gamma$ ) and IL12, which protect against viral infections and other intracellular pathogens. Th 17 is a highly pro-inflammatory arm characterised by rapid induction of neutrophils at the inflamed tissue and requires IL-I and IL- 6 for its activation. In contrast, parasitic infections drive Th2 immune responses characterized by production of IL-4 and IL- I3, which mediate elimination of multicellular parasites. In addition to driving polarized Th2 responses, parasitic infections are associated with the induction of Tregs and immunoregulatory IL-10, which can induce immune anergy. The resultant effect of this is that parasitic infections can be characterized by an overall down-regulated immune system and therefore modified Th2-response, termed Th2-like. Because many cytokines can be produced and utilised by a number of different cells (IL- I0 being a good example [I06]), it is clear that multiple cell types may contribute to the regulation of the type and extent of inflammation. Thus, immune regulation likely depends on the specific combination of different $\mathrm{T}$ cells called upon during an infection than on a clear predominance of one response profile.

conserved in all vertebrates including the jawless lamprey $[80,81]$. This highly pro-inflammatory CD4+ Th subset plays an important role in the immediate responses to injuries with high risk of necrosis [82], and in protection against extracellular pathogens which are not efficiently cleared by Th1-type and Th2-type immunity [83]. The outcome of parasitic infections may be determined by the balance of pro-inflammatory and regulatory immune 
responses. Our observations indicate that reactions to SL in Atlantic salmon are consistent with the bias towards the regulatory/Th2-like responses.

Identification of genes involved in the Th1/Th2 axis was greatly enhanced with the sequencing of several fish genomes $[80,84]$. The cytokine networks are becoming increasingly better known in fish. Overall, fish possess a repertoire of cytokines, which is similar to mammalian $[85,86]$, including recently cloned IL-6 [87,88], IL-12 [89] and IL-10 [90-93]. First Th2 type interleukin, IL-4 was cloned in 2007 [94]. Also recently, the master regulators of Th1 and Th2 development, T-bet and GATA-3, respectively, were described in fish $[95,96]$. Cytokine profiles alone are insufficient for the accurate assignment of T cells to lineages given that cytokines may work in different ways. For example TGF- $\beta$ induces development of both Treg and Th17 in mice and suppresses Treg development in humans [97]. One may anticipate much greater differences between mammals and teleost fish.

Rapid involvement of $\mathrm{T}$ cells in response to infection in skin was implied already $3 \mathrm{dpi}$. However, the delayed healing in SL infected Atlantic salmon may indicate an impaired or modified, Th2-like response. Long lived parasites often cause chronic infections via the induction of Treg cells and concomitant down-regulation of protective Th responses [71]. The involvement of a Treg-like subset, as implied by the up-regulation of TGF- $\beta$ and IL-10 at 33 dpi, was not seen in the chronic phase of SL infection. This coincided with the molting of pre-adults into mobile adult stages. Though probably down modulatory towards the effector Th arms in fish, IL-10 and TGF- $\beta$ may benefit the host at this stage due to the reduced damage caused by inflammatory reactions and/or enhanced healing response. The augmented healing would not harm SL either, as most chalimii molted into mobile life stages 33 dpi and maintenance of an open wound to aid in feeding may not have been necessary. We also observed the regulations of gene expression in the internal organs, which were consistent with changes in the skin. Early activation of the humoral response, as evidenced by the transcriptional wave of immunoglobulin-like genes, was followed by general hyporesponsiveness during immobile SL stages 22 dpi (Fig. 3B and 3A). Expression profiles of immunoglobulins partially reverted $33 \mathrm{dpi}$ only in the spleen.

Possible roles of cells and the regulatory network are presented in Figure 6. Interestingly, the expression profile of programmed death ligand 1 (PD-L1), a negative co-stimulatory signal of T cell activation [98], was similar to that of CD4. The differential regulation of all-trans-13,14dihydroretinol saturase in skin, liver and spleen also implies a dynamic regulation of immune cells through retinol signalling (Fig. 1B and Fig. 3A). Vitamin-A defi- ciency is known to induce immune abnormalities in T-cell subsets [99-101]. Retinoic acid signalling was recently shown to inhibit Th17 and promote Treg differentiation [102]. Interestingly, two structurally novel protein families with a high affinity to retinol and fatty acids, potentially playing a role in modifying inflammatory environment were identified in parasitic nematodes $[103,104]$.

The skin expression profile of cytochrome P450 27, which ties together retinoid, PPAR $\gamma$ and LXR signaling [105] implies the down regulation of a whole regulatory network based on natural/endogenous ligands: retinoids and modified fatty acids and prostanoids (Fig. 1B). Of note is the observation that all-trans-13,14-dihydroretinol saturase is down regulated in skin and liver but from $22 \mathrm{dpi}$ becomes up-regulated in spleen. In addition, 5-lipoxygenase binding protein, involved in the generation of leukotrienes, another set of lipid mediators of immunity was upregulated throughout the study period in head kidney. Such expression profiles may stem from the fact that skin is under the direct and stronger modulation by the parasite than the internal organs.

\section{Conclusion}

Initial infection of Atlantic salmon with SL is associated with rapid sensing and induction of mixed inflammatory responses. A combination of restricted inflammation, which can be due to hyporesponsiveness of the immune cells, and delayed healing of injuries, can account for the limited ability to reject parasites. Persistent infection of Atlantic salmon with SL implies compromised immunity and self-destruction of tissues. Development of markers for different subsets of salmon T cells will greatly enhance the opportunity to study responses of Atlantic salmon to $\mathrm{SL}$, and other parasites.

\section{Materials and methods Challenge test}

Salmon used for this experiment originated from the Aqua Gen AS (previously referred to as NLA) strain. Salmon smolts of mixed and unknown family background were transferred to Institute of Marine Research in Bergen, transferred to full salinity saltwater, and distributed into two replicate tanks (two control and two for $L$. salmonis infection). Fish were hand fed a commercial diet once daily during the entire experimental period. Water temperature was $10^{\circ} \mathrm{C} \pm 1.5^{\circ} \mathrm{C}$ during the entire experimental period. Egg strings from hatchery reared SL were collected and placed into single incubators. Approximately 75 infectious copepodids/fish were used to infect 40 salmon (20/tank). On the day of infection, the water level in the replicate tanks was reduced to approximately one third of the tanks original volume, the water supply was stopped, and the water was aerated with oxygen. One 


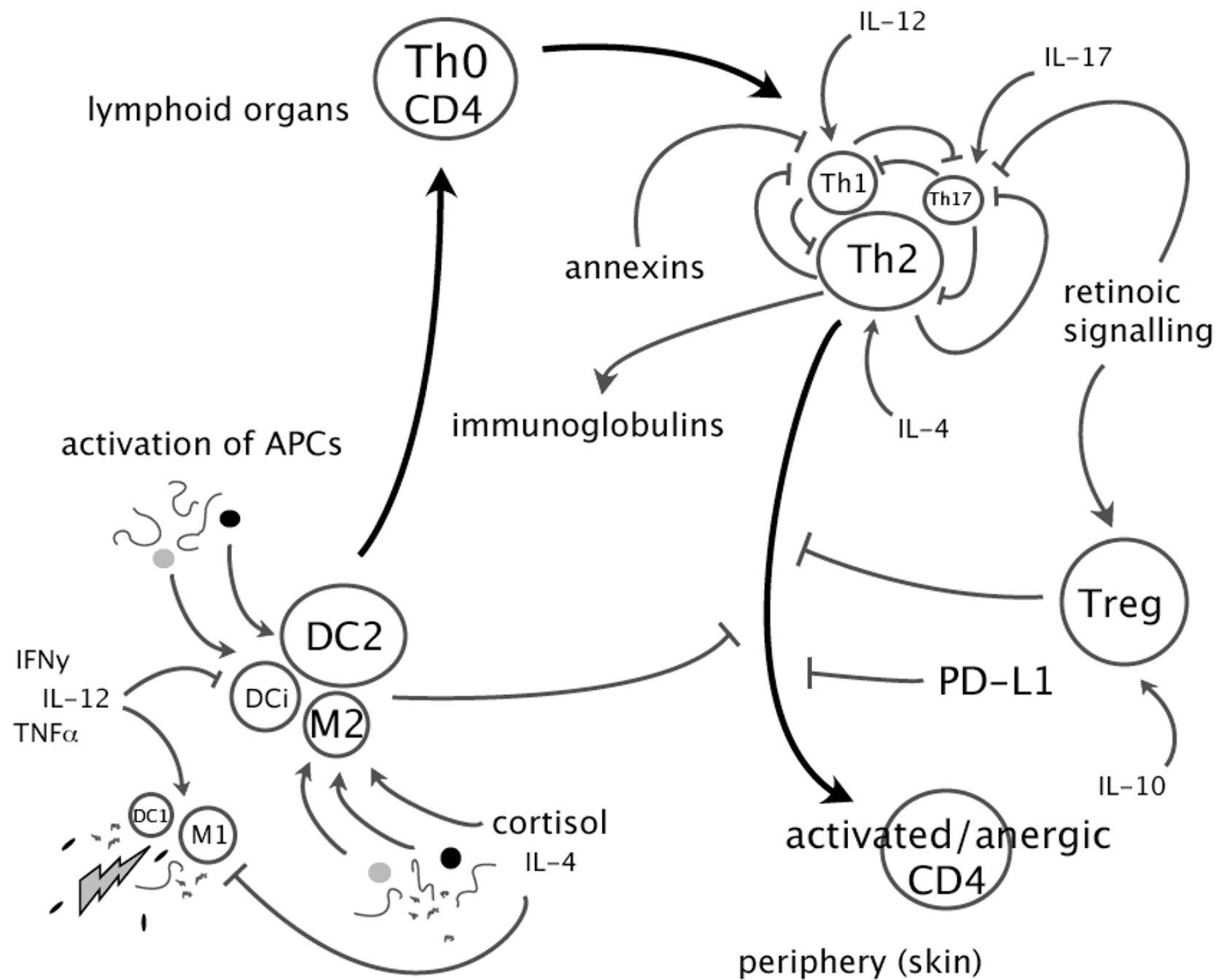

\section{Figure 6}

Hypothetical model of responses of immune cells to SL. Classical activation of macrophages (M) and dendritic cells (DC) induces $\mathrm{MI}$ and DCI phenotypes, which drive CD4+ T cells toward Th I. In contrast, SL may selectively induce C-type lectin receptors and possibly other receptor classes on alternatively activated macrophages (M2), immature DC (DCi) and DC2 to preferentially induce Th2 cells [75]. Parasite antigens are presented to CD4+ T cells in lymphoid tissues. Upon activation, Th2 cells proliferate and induce immunoglobulin production, possibly down-regulating other Th subsets. However, different subsets can coexist and a balanced combination may result in susceptibility or resistance. Activated Th2 cells migrate to the site of SL attachment where they mediate expulsion of chalimus larvae. Antagonism within the Th compartment and suppression by Treg cells can inhibit CD4+ T cell effector functions. Several other mechanisms can have key functions in the shaping of the $\mathrm{T}$ cell repertoire, and in regulation of inflammatory responses to SL, including reciprocal Th 17 and Treg differentiation mediated by vitamin A derivatives [107] and various anti-inflammatory agents, such as annexins. Programmed death ligand I (PD-LI) possibly provides a distinct negative regulatory checkpoint in T cell differentiation [98]. Endogenous products (e.g. cortisol and prostaglandins), cellular debris and SL products are also able to potently influence immune responses [I08-I I0].

hour post infection, the water supply was reinstated and oxygen supply to the tanks removed.

The experimental fish were sampled on the following dates: 21.09.2006 (3 dpi = copepodids), 11.10. 2006 (22 $\mathrm{dpi}=$ chalimus III/IV), and 21.10.2006. (33 dpi = preadult females and males) (Fig. 7A). At 22 dpi the number of lice per fish ranged from 4 to 20 with mean $12.2 \pm 1.8$. Individuals with average numbers of parasites were used for analyses. Control fish were sampled in parallel with 


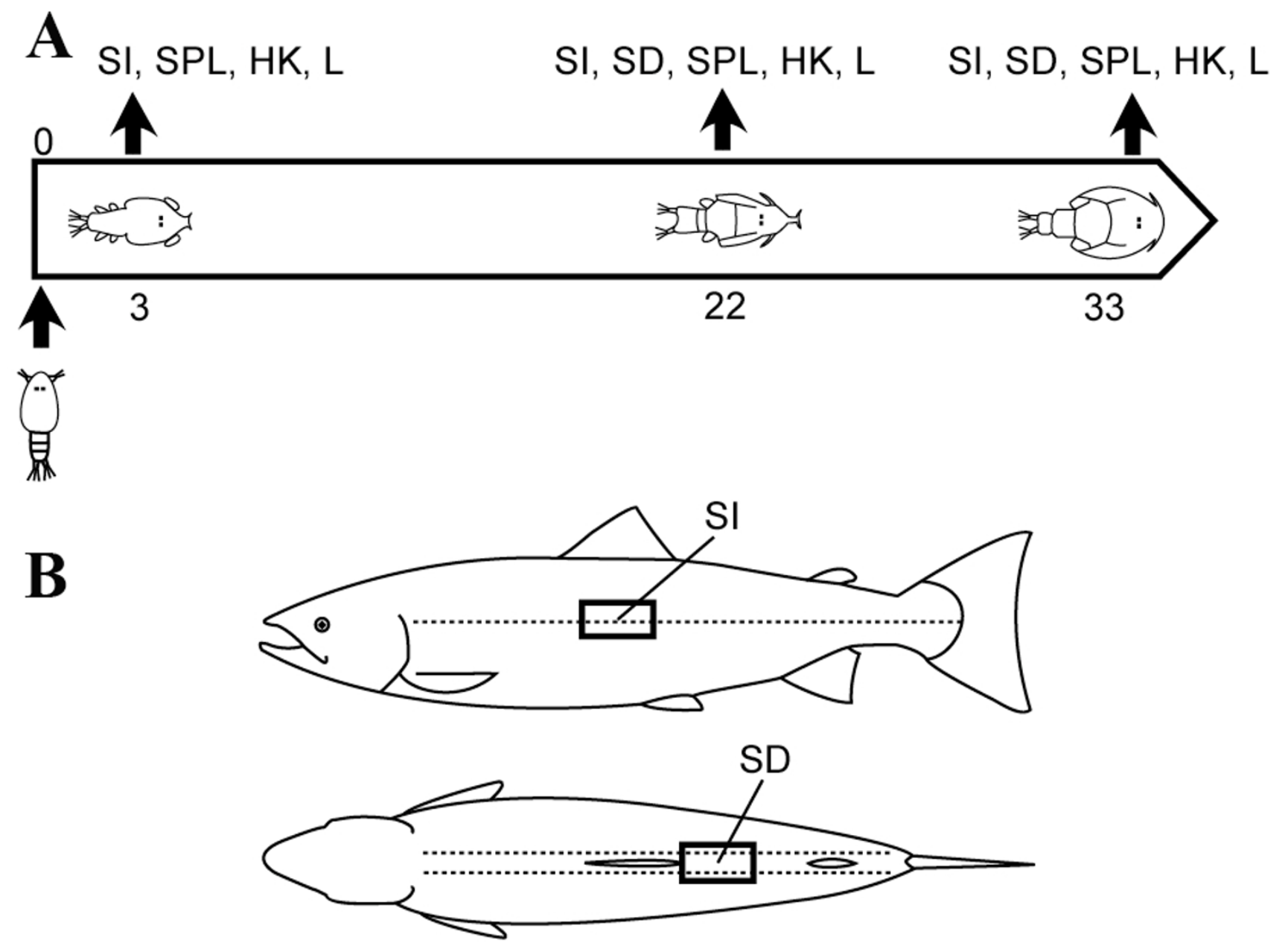

\section{Figure 7}

Design of the experiment.A: Two study groups of Atlantic salmon were SL infected fish with approximately 75 copepodids per fish. On days 3, 22 and 33 tissue samples were collected from the control and infected test groups; time-points corresponded to copepodids ( $3 \mathrm{dpi}$ ), chalimus III/IV (22 dpi) and preadult stages ( $33 \mathrm{dpi})$. B: Due to the small size of SL at the copepodid stage, it was not possible to reliably locate them on fish at the sample taken $3 \mathrm{dpi}$. Consequently, SL damaged skin was only sampled $22 \mathrm{dpi}$ and $33 \mathrm{dpi}$. Salmon lice tend to aggregate around fins. Therefore, the area behind the dorsal fin was chosen in order to sample damaged skin. Because attached lice were never found along the lateral line, samples of intact skin of infected fish were taken from the area below the dorsal fin at the intersection with the lateral line. SI - intact skin; SD - damaged skin; SPL - spleen; HK - head kidney; L - liver; dpi - days post infection.

challenged fish. In addition to skin, samples of the head kidney, spleen and liver were collected and preserved in RNALater (Ambion, Austin, TX, USA) (Fig 7B). Lice induced damage to the fish was moderate, and no open wounds were observed on any of the experimental fish. Furthermore, there was no evidence of any secondary infections either on the surface or internal organs for the infected or control fish.

\section{Microarray analyses}

The salmonid fish microarray (SFA2, immunochip) includes 1800 unique clones printed each in six spot rep- licates. The genes were selected by their functional roles and the platform is enriched in a number of functional classes, such as immune response (236 genes), cell communication (291 genes), signal transduction (245 genes), protein catabolism ( 90 genes) and folding ( 70 genes). The complete composition of platform and sequences of genes are provided in submission to NCBI GEO (GPL6154). Total RNA was extracted from soft tissues with TriZOL (Invitrogen, Carlsbad, CA, USA), whilst Fibrous tissue kit (Qiagen sciences, Maryland, USA) was used with skin. Total RNA was purified with Pure Link (Invitrogen, Carlsbad, CA, USA). Microarray analyses 
Table I: Real-time qPCR analyses

\begin{tabular}{|c|c|c|c|}
\hline Target & Primer sequence from 5 ' to $3^{\prime}$ & Amplicon size (bp) & Accesion number \\
\hline \multirow[t]{2}{*}{ Matrix metalloproteinase 13} & F CCAAAAAGAGGGCACCAGATGG & 53 & DW539943 \\
\hline & R CCAAAAAGAGGGCACCAGATGG & & \\
\hline \multirow[t]{2}{*}{ Matrix metalloproteinase 9} & F AGTCTACGGTAGCAGCAATGAAGGC & 72 & CA342769 \\
\hline & R CGTCAAAGGTCTGGTAGGAGCGTAT & & \\
\hline \multirow[t]{2}{*}{ Cathepsin S } & F CGAAGGGAGGTCTGGGAGAGGAAT & 87 & CA355014 \\
\hline & R GCCCAGGTCATAGGTGTGCATGTC & & \\
\hline \multirow[t]{2}{*}{ Bone morphogenetic protein 4} & F TCAAGTTGCCCATAGTCAGT & 207 & CA056395 \\
\hline & R CACCTGAACTCTACCAACCA & & \\
\hline \multirow[t]{2}{*}{ Alkaline phosphatase } & F CTAGTTTGGGTCGTGGTATGT & 185 & CA358635 \\
\hline & R TGAGGGCATTCTTCAAAGTA & & \\
\hline \multirow[t]{2}{*}{ Heat shock protein $90 \beta-20$} & F GAACCTCTGCAAGCTCATGAAGGA & 72 & CF752846 \\
\hline & R ACCAGCCTGTTTGACACAGTCACCT & & \\
\hline \multirow[t]{2}{*}{ Collagen $10 \alpha$} & F TGGTGCTCTTTGACTGCCTGTAA & 180 & EG837|48 \\
\hline & R CATCCTGTGTGTTGCAATATCACA & & \\
\hline \multirow[t]{2}{*}{ Collagen $I \alpha$} & F AGAGAGGAGTCATGGGACCCGTT & 155 & \\
\hline & R GGGTCCTGGAAGTCCCTGGAAT & & \\
\hline \multirow[t]{2}{*}{ Collagen $2 \alpha$} & F TGGTCGTTCTGGAGAGACT & 151 & BX865386 \\
\hline & R CCTCATGTACCTCAAGGGAT & & \\
\hline \multirow[t]{2}{*}{ Decorin } & F GAACCTGGCTAAGCTGGGTCTAA & 256 & DQ452069 \\
\hline & R GAACAGGCTGATGCCAGAGTACAT & & \\
\hline \multirow{2}{*}{ Elastin } & F GAGGCTACAGACCAGGAGGAGTT & 226 & BU694I49 \\
\hline & R TCTGGGTCGGTGGGTTTGTA & & \\
\hline \multirow[t]{2}{*}{ Laminin } & F CATGTGACATGGACACAGGAA & 273 & DY722974 \\
\hline & R CGTCCTCAGCCTCATAGGTGTA & & \\
\hline \multirow[t]{2}{*}{ CCAAT/enhancer binding protein $\beta$} & F TACGTCCTGGGCTATCCTGAACTGC & 140 & CA348284 \\
\hline & R CCAGACGAACCGTTGTTGTCCA & & \\
\hline \multirow{2}{*}{ Erythroid 5-aminolevulinate synthas } & F CACATGAGACAGCTGCTCCTGGAGA & 121 & DW580939 \\
\hline & R GCTCCAGCAAGATGTCACACACCT & & \\
\hline \multirow[t]{2}{*}{ Heme oxygenase I } & F AGTCAGTGGAGAGAGACCTGGAGCA & 117 & $\underline{\text { CA363120 }}$ \\
\hline & R GGTTGTCTTTGCCGATCTGTCTGAG & & \\
\hline \multirow[t]{2}{*}{ Haemoglobin beta chain } & F ACAAACGTCAACATGGTCGACTGG & 67 & NM 001123666 \\
\hline & R TCTTTCCCCACAGGCCTACGAT & & \\
\hline \multirow[t]{2}{*}{ Mannose binding lectin I } & F TCCATTGCACTGGGCGATGC & 105 & CA349943 \\
\hline & R CACTGCTTCCACCTGAGCCTCA & & \\
\hline \multirow[t]{2}{*}{ Prostaglandin D synthase } & F CCTACACCAACCTGAACGCTGATG & 98 & CA352578 \\
\hline & R ACGCTGGCTGGTGAAGGTGAAG & & \\
\hline MHC class II $\alpha$ chain & F AGTCAGGTGGACCAGGAACAATCA & 96 & CA379977 \\
\hline & R CTGGAGAACTGGTTGAGGGTGAAA & & \\
\hline $\operatorname{CD} 8 \alpha$ & F CGTCTACAGCTGTGCATCAATCAA & 266 & AY693391 \\
\hline & R GGCTGTGGTCATTGGTGTAGTC & & \\
\hline IL-I $2 \beta$ & F TCTACCTACACGACATTGTCCAGCC & 62 & A]548830 \\
\hline & R ATCCATCACCTGGCACTTCATCC & & \\
\hline Arginase I & F AGCCATGCGTATCAGCCAA & 122 & EG929369 \\
\hline & AAGGCGATCCACCTCAGTCA & & \\
\hline Programmed death ligand I & F TCAACGACTCTGGGGTGTACCGATG & 133 & CA366631 \\
\hline & R TCCACСТСАТСТССАССАСGTCTC & & \\
\hline Beta-2-microglobulin & F TCGTTGTACTTGTGCTCATTTACAGC & 107 & AFI80478 \\
\hline & R CAGGGTATTCTTATCTCCAAAGTTGC & & \\
\hline TGF- $\beta$ & F AATCGGAGAGTTGCTGTGTGCGA & 332 & EU082211+ \\
\hline & R GGGTTGTGGTGCTTATACAGAGCCA & & Aj007836 \\
\hline IL-I receptor type I & F CCAAAAAGAGGGCACCAGATGG & 126 & NM 001123633 \\
\hline & R CGTATCGTCTCTCCAACACCTCAGG & & \\
\hline CD4 & F TGCATTGTTCCTCTCTTCCACAGC & 128 & EG852912 \\
\hline & R CCGTCCCAAGGTACCATAGTACCAA & & \\
\hline IL-10 & F ATGAGGCTAATGACGAGCTGGAGA & 54 & $\underline{E F I 65028}$ \\
\hline & R GGTGTAGAATGCCTTCGTCCAACA & & \\
\hline Eukaryotic translation initiation factor 3 subunit 6 & F GTCGCCGTACCAGCAGGTGATT & 92 & CX040383 \\
\hline & R CGTGGGCCATCTTCTTCTCGA & & \\
\hline
\end{tabular}


were conduced in pooled samples with equal inputs of RNA from six individuals. A dye swap design of hybridization was applied. In analyses of injured skin, the intact sites from the same individuals were used as a control. Microarray comparisons were also conducted with intact skin from challenged and control fish; these data were not reported due to relatively small expression changes. Analyses of head kidney, spleen and liver used the uninfected fish as a reference. Each sample was analyzed with two slides. The control and test samples (20 $\mu \mathrm{g}$ RNA in each) were labelled with respectively Cy3-dUTP and Cy5-dUTP (Amersham Pharmacia, Little Chalfont, UK) for the first slide and dye assignment was reversed for the second slide. The fluorescent dyes were incorporated in cDNA using the SuperScript ${ }^{\mathrm{TM}}$ Indirect cDNA Labelling System (Invitrogen, Carlsbad, CA, USA). The cDNA synthesis was performed at $46^{\circ} \mathrm{C}$ for 3 hours in a $20 \mu \mathrm{l}$ reaction volume, following RNA degradation with $0.2 \mathrm{M} \mathrm{NaOH}$ at $37^{\circ} \mathrm{C}$ for $15 \mathrm{~min}$ and alkaline neutralization with $0.6 \mathrm{M}$ Hepes. Labelled cDNA was purified with Microcon YM30 (Millipore, Bedford, MA, USA). The slides were pretreated with $1 \%$ BSA fraction $\mathrm{V}, 5 \times \mathrm{SSC}, 0.1 \%$ SDS $\left(30 \mathrm{~min}\right.$ at $\left.50^{\circ} \mathrm{C}\right)$ and washed with $2 \times \operatorname{SSC}(3 \mathrm{~min})$ and $0.2 \times \operatorname{SSC}(3 \mathrm{~min})$ and hybridized overnight at $60^{\circ} \mathrm{C}$ in a cocktail containing $1.3 \times$ Denhardt's, $3 \times$ SSC $0.3 \%$ SDS, $0.67 \mu \mathrm{g} / \mu \mathrm{l}$ polyadenylate and $1.4 \mu \mathrm{g} / \mu \mathrm{l}$ yeast tRNA. After hybridization slides were washed at room temperature in $0.5 \times$ SSC and $0.1 \%$ SDS (15 min), $0.5 \times$ SSC and $0.01 \%$ SDS (15 min), and twice in $0.06 \times \operatorname{SSC}(2$ and $1 \mathrm{~min}$, respectively). Scanning was performed with GSI Lumonics ScanArray 4000 (PerkinElmer Life Sciences, Zaventem, Belgium) and images were processed with GenePix 6.0 (Axon, Union City, CA, USA). The spots were filtered by criterion $(I-B) /\left(S_{I}+S_{B}\right) \geq$ 0.6 , where $I$ and $B$ are the mean signal and background intensities and $S_{I}, S_{B}$ are the standard deviations. Low quality spots were excluded from analysis and genes presented with less than three high quality spots on a slide were discarded. After subtraction of median background from median signal intensities, the expression ratios (ER) were calculated. Lowess normalization was performed first for the whole slide and next for twelve rows and four columns per slide. The differential expression was assessed by difference of the mean log-ER between the slides with reverse labelling ( 6 spot replicates per gene on each slide, Student's t-test, $\mathrm{p}<0.01)$. Complete microarray results are provided as an additional file 1 .

\section{Quantitative real-time $R T-P C R$}

The cDNA synthesis was performed on $2 \mu \mathrm{g}$ of DNAse treated (Turbo DNA-free ${ }^{\mathrm{TM}}$ (Ambion, Austin, TX, USA) total RNA using TaqMan ${ }^{\circledast}$ Reverse Transcription reagents (Applied Biosystems, Foster City, CA, USA) and random hexamer primers. The PCR primers (Table 1) were designed using the Vector NTI (Invitrogen) and synthesized by Invitrogen. PCR. Efficiency was checked from ten- fold serial dilutions of cDNA for each primer pair (additional file 2). Real-time PCR assays were conduced using 2X SYBR ${ }^{\circledast}$ Green Master Mix (Roche Diagnostics, Mannheim, Germany) in a $12 \mu \mathrm{l}$ reaction volume, primer concentrations were $0.4-0.6 \mu \mathrm{M}$ each. PCR was performed in duplicates in 96-well optical plates on Light Cycler 480 (Roche Diagnostics). Relative expression of mRNA was calculated using the $\Delta \Delta \mathrm{C}_{\mathrm{T}}$ method; the chosen reference gene for all tissues was eukaryotic translation initiation factor 3 subunit 6 (eIF3S6), which showed no differential expression according to the microarray results. Two more commonly used genes (EF1A and GAPDH) were tested for stability using the GeNorm software, however only eIF3S6 met criteria of stability in the analyzed material. Differences between infected and control fish were analyzed with Student's t-test $(\mathrm{p}<0.05)$.

\section{Competing interests}

The authors declare that they have no competing interests.

\section{Authors' contributions}

All authors contributed to the overall experimental design. KG and FN designed and performed the challenge tests, whilst SS and AK carried out the gene expression analyses, data analysis, and produced the first manuscript draft. All authors read, contributed to, and approved the final manuscript.

\section{Additional material}

\author{
Additional file 1 \\ Complete results of microarray analyses. Data are log (Expression \\ ratios) and $p$-values of differential expression ( $t$ test). \\ Click here for file \\ [http://www.biomedcentral.com/content/supplementary/1471- \\ 2164-9-498-S1.xls]

\section{Additional file 2} \\ Efficiency of PCR. \\ Click here for file \\ [http://www.biomedcentral.com/content/supplementary/1471- \\ 2164-9-498-S2.doc]
}

\section{Acknowledgements}

This study was supported with a grant from the National Research Council of Norway ( 173490//30). We wish to thank Turku Centre of Biotechnology for the preparation of microarrays and Elisabeth Ytteborg for assistance with qPCR.

\section{References}

I. Johnson SC, Fast MD: Interactions between sea lice and their hosts. Symp Soc Exp Biol 2004:131-159.

2. Pike AW, Wadsworth SL: Sealice on salmonids: Their biology and control. Advances in Parasitology 2000, 44:233-337.

3. Costello MJ: Ecology of sea lice parasitic on farmed and wild fish. Trends in Parasitology 2006, 22:475-483. 
4. Krkosek M, Ford JS, Morton A, Lele S, Myers RA, Lewis MA: Declining wild salmon populations in relation to parasites from farm salmon. Science 2007, 3 I 8: | 1772- 1775.

5. Tully O, Nolan DT: A review of the population biology and host-parasite interactions of the sea louse Lepeophtheirus salmonis (Copepoda: Caligidae). Parasitology 2002 I 24:SI65-SI82

6. Wagner GN, Fast MD, Johnson SC: Physiology and immunology of Lepeophtheirus salmonis infections of salmonids. Trends in Parasitology 2008, 24: I76-183.

7. Dawson LHJ, Pike AW, Houlihan DF, McVicar AH: Comparison of the susceptibility of sea trout (Salmo trutta L.) and Atlantic salmon (Salmo salar L.) to sea lice (Lepeophtheirus salmonis (Kroyer, 1837)) infections. Ices Journal of Marine Science 1997, 54: I129-1139.

8. Johnson SC, Albright LJ: Comparative Susceptibility and Histopathology of the Response of Naive Atlantic, Chinook and Coho Salmon to Experimental-Infection with Lepeophtheirus-Salmonis (Copepoda, Caligidae). Diseases of Aquatic Organisms 1992, 14:179-193.

9. Jones SRM, Fast MD, Johnson SC, Groman DB: Differential rejection of salmon lice by pink and chum salmon: disease consequences and expression of proinflammatory genes. Diseases of Aquatic Organisms 2007, 75:229-238.

10. Nagasawa K, Takami T: Host Utilization by the Salmon Louse Lepeophtheirus-Salmonis (Copepoda, Caligidae) in the Sea of Japan. Journal of Parasitology 1993, 79:127-130.

II. Fast MD, Ross NW, Mustafa A, Sims DE, Johnson SC, Conboy GA, et al.: Susceptibility of rainbow trout Oncorhynchus mykiss, Atlantic salmon Salmo salar and coho salmon Oncorhynchus kisutch to experimental infection with sea lice Lepeophtheirus salmonis. Dis Aquat Organ 2002, 52:57-68.

12. Fast MD, Muise DM, Easy RE, Ross NW, Johnson SC: The effects of Lepeophtheirus salmonis infections on the stress response and immunological status of Atlantic salmon (Salmo salar). Fish \& Shellfish Immunology 2006, 2 I:228-24I.

13. Koskinen H, Pehkonen P, Vehniainen E, Krasnov A, Rexroad C, Afanasyev S, et al: Response of rainbow trout transcriptome to model chemical contaminants. Biochemical and Biophysical Research Communications 2004, 320:745-753.

14. Krasnov A, Koskinen H, Pehkonen P, Rexroad CE, Afanasyev S, Molsa $\mathrm{H}$ : Gene expression in the brain and kidney of rainbow trout in response to handling stress. Bmc Genomics 2005, 6:

15. Jorgensen SM, Afanasyev S, Krasnov A: Gene expression analyses in Atlantic salmon challenged with infectious salmon anemia virus reveal differences between individuals with early, intermediate and late mortality. Bmc Genomics 2008, 9: 179.

16. Geijtenbeek TBH, Krooshoop DJEB, Bleijs DA, van Vliet SJ, van Duijnhoven GCF, Grabovsky V, et al.: DC-SIGN-ICAM-2 interaction mediates dendritic cell trafficking. Nature Immunology 2000, I:353-357.

17. Gordon S: Pattern recognition receptors: Doubling up for the innate immune response. Cell 2002, I I I:927-930.

18. Figdor CG, van Kooyk Y, Adema G]: C-type lectin receptors on dendritic cells and Langerhans cells. Nature Reviews Immunology 2002, 2:77-84

19. van Vliet SJ, den DJ, Gringhuis SI, Geijtenbeek TB, van KY: Innate signaling and regulation of Dendritic cell immunity. Curr Opin Immunol 2007, 19:435-440.

20. Egeblad M, Werb Z: New functions for the matrix metalloproteinases in cancer progression. Nature Reviews Cancer 2002 , 2: $161-174$

21. Brinckerhoff CE, Matrisian LM: Timeline - Matrix metalloproteinases: a tail of a frog that became a prince. Nature Reviews Molecular Cell Biology 2002, 3:207-2I4.

22. Nerlov C: The C/EBP family of transcription factors: a paradigm for interaction between gene expression and proliferation control. Trends in Cell Biology 2007, I 7:318-324.

23. Friedman SG, Czura CJ, Tracey KJ: The gesture life of high mobility group box I. Current Opinion in Clinical Nutrition and Metabolic Care 2003, 6:283-287.

24. Arima K, Sato K, Tanaka G, Kanaji S, Terada T, Honjo E, et al.: Characterization of the interaction between interleukin- 13 and interleukin-13 receptors. Journal of Biological Chemistry 2005, 280:24915-24922.
25. Murphy KM, Ouyang W, Farrar JD, Yang JF, Ranganath S, Asnagli H, et al.: Signaling and transcription in $\mathbf{T}$ helper development. Annual Review of Immunology 2000, I 8:45 I-494.

26. Sutton C, Brereton C, Keogh B, Mills KHG, Lavelle EC: A crucial role for interleukin (IL)-I in the induction of IL-I 7-producing $\mathbf{T}$ cells that mediate autoimmune encephalomyelitis. Journal of Experimental Medicine 2006, 203:I685-I69I.

27. Cools N, Ponsaerts P, Van TV, Berneman ZN: Regulatory T cells and human disease. Clin Dev Immunol 2007, 2007:89195.

28. Gonzalez SF, Chatziandreou N, Nielsen ME, Li WZ, Rogers J, Taylor $\mathrm{R}$, et al: Cutaneous immune responses in the common carp detected using transcript analysis. Molecular Immunology 2007, 44: I664-I679.

29. Gerke V, Moss SE: Annexins: From structure to function. Physiological Reviews 2002, 82:33|-37|.

30. Harris SG, Padilla J, Koumas L, Ray D, Phipps RP: Prostaglandins as modulators of immunity. Trends in Immunology 2002, 23: I44-I 50.

31. Castrillo A, az-Guerra MJM, Hortelano S, Martin-Sanz P, Bosca L: Inhibition of I kappa B kinase and I kappa B phosphorylation by $\mid 5$-deoxy-Delta( $12, \mid 4)$-prostaglandin $J(2)$ in activated murine macrophages. Molecular and Cellular Biology 2000 , 20:1692-1698.

32. Rossi A, Kapahi P, Natoli G, Takahashi T, Chen Y, Karin M, et al: Anti-inflammatory cyclopentenone prostaglandins are direct inhibitors of I kappa B kinase. Nature 2000, 403: I03-108.

33. Clark RB, Bishop-Bailey D, Estrada-Hernandez T, Hla T, Puddington $L$, Padula SJ: The nuclear receptor PPAR gamma and immunoregulation: PPAR gamma mediates inhibition of helper $\mathbf{T}$ cell responses. Journal of Immunology 2000, I 64: | 364- I37|

34. Malhotra JD, Kaufman RJ: The endoplasmic reticulum and the unfolded protein response. Semin Cell Dev Biol 2007, I 8:716-73I.

35. Ross NW, Firth KJ, Wang AP, Burka JF, Johnson SC: Changes in hydrolytic enzyme activities of naive Atlantic salmon Salmo salar skin mucus due to infection with the salmon louse Lepeophtheirus salmonis and cortisol implantation. Diseases of Aquatic Organisms 2000, 41:43-51.

36. Fouda MM, Miller PJ: Alkaline-Phosphatase Activity in the Skin of the Common Goby, Pomatoschistus-Microps (Kroyer), in Relation to Cycles in Scale and Body Growth. Journal of Fish Biology 1979, I 5:263.

37. Chunn JL, Mohsenin A, Young HWJ, Lee CG, Elias JA, Kellems RE, et al.: Partially adenosine deaminase-deficient mice develop pulmonary fibrosis in association with adenosine elevations. American Journal of Physiology-Lung Cellular and Molecular Physiology 2006, 290:L579-L587.

38. Kuno M, Seki N, Tsujimoto S, Nakanishi I, Kinoshita T, Nakamura K, et al.: Anti-inflammatory activity of non-nucleoside adenosine deaminase inhibitor FR234938. European Journal of Pharmacology 2006, 534:24I-249.

39. Peters-Golden M, Brock TG: 5-lipoxygenase and FLAP. Prostaglandins Leukotrienes and Essential Fatty Acids 2003, 69:99-109.

40. Pouliot M, Fiset ME, Masse M, Naccache PH, Borgeat P: Adenosine up-regulates cyclooxygenase- 2 in human granulocytes: Impact on the balance of eicosanoid generation. Journal of Immunology 2002, 1 69:5279-5286.

4I. Nie YC, Han YC, Zou YR: CXCR4 is required for the quiescence of primitive hematopoietic cells. Journal of Experimental Medicine 2008, 205:777-783.

42. Valenick LV, Hsia HC, Schwarzbauer JE: Fibronectin fragmentation promotes alpha 4 beta $I$ integrin-mediated contraction of a fibrin-fibronectin provisional matrix. Experimental Cell Research 2005, 309:48-55.

43. Kwon AH, Qiu ZY, Hirao Y: Topical application of plasma fibronectin in full-thickness skin wound healing in rats. Experimental Biology and Medicine 2007, 232:935-94I.

44. Martin P: Wound healing - Aiming for perfect skin regeneration. Science 1997, 276:75-81.

45. Raghow R: The Role of Extracellular-Matrix in Postinflammatory Wound-Healing and Fibrosis. Faseb Journal 1994 , 8:823-83I.

46. Matsumoto $R$, Sugimoto $M$ : Dermal matrix proteins initiate reepithelialization but are not sufficient for coordinated epidermal outgrowth in a new fish skin culture model. Cell and Tissue Research 2007, 327:249-265 
47. Adzick NS, Lorenz HP: Cells, Matrix, Growth-Factors, and the Surgeon - the Biology of Scarless Fetal Wound Repair. Annals of Surgery 1994, 220:10-18.

48. Falanga V: Wound healing and its impairment in the diabetic foot. Lancet 2005, 366:1736-1743.

49. Robson MC, Steed DL, Franz MG: Wound healing: Biologic features and approaches to maximize healing trajectories - In brief. Current Problems in Surgery 2001, 38:65-140.

50. Dugan TA, Yang VW, McQuillan DJ, Hook M: Decorin modulates fibrin assembly and structure. I Biol Chem 2006, 28 I:38208-382 I 6

51. Johnson PY, Potter-Perigo S, Gooden MD, Vernon RB, Wight TN: Decorin synthesized by arterial smooth muscle cells is retained in fibrin gels and modulates fibrin contraction. Journal of Cellular Biochemistry 2007, I 0 I:281-294.

52. Ameye L, Young MF: Mice deficient in small leucine-rich proteoglycans: novel in vivo models for osteoporosis, osteoarthritis, Ehlers-Danlos syndrome, muscular dystrophy, and corneal diseases. Glycobiology 2002, I 2: I07R-I I6R.

53. Werner S, Grose R: Regulation of wound healing by growth factors and cytokines. Physiol Rev 2003, 83:835-870.

54. Xue ML, Le NTV, Jackson CJ: Targeting matrix metalloproteases to improve cutaneous wound healing. Expert Opinion on Therapeutic Targets 2006, 10:143-155.

55. Roberts $A B$, Heine UI, Flanders KC, Sporn MB: Transforming Growth-Factor-Beta - Major Role in Regulation of Extracellular-Matrix. Annals of the New York Academy of Sciences 1990, 580:225-232.

56. Daley WP, Peters SB, Larsen M: Extracellular matrix dynamics in development and regenerative medicine. Journal of Cell Science 2008, I 2 I:255-264.

57. Engler AJ, Sen S, Sweeney HL, Discher DE: Matrix elasticity directs stem cell lineage specification. Cell 2006, I 26:677-689.

58. Grinnell KL, Bickenbach JR: Skin keratinocytes pre-treated with embryonic stem cell-conditioned medium or BMP4 can be directed to an alternative cell lineage. Cell Proliferation 2007, 40:685-705.

59. Botchkarev VA: Bone morphogenetic proteins and their antagonists in skin and hair follicle biology. Journal of Investigative Dermatology 2003, I 20:36-47.

60. Firth KJ, Johnson SC, Ross NW: Characterization of proteases in the skin mucus of Atlantic salmon (Salmo salar) infected with the salmon louse (Lepeophtheirus salmonis) and in whole-body louse homogenate. J Parasitol 2000, 86: I I99-I 205.

6I. McKerrow JH, Caffrey C, Kelly B, Loke P, Sajid M: Proteases in parasitic diseases. Annu Rev Pathol 2006, I:497-536.

62. Berghe W Vanden, Vermeulen L, Delerive P, De Bosscher K, Staels B, Haegeman G: A paradigm for gene regulation: Inflammation, NF-kappa B and PPAR. Peroxisomal Disorders and Regulation of Genes 2003, 544:181-196.

63. Gharavi N, El-Kadi AOS: Role of nitric oxide in downregulation of cytochrome P450 I a I and NADPH: quinone oxidoreductase I by tumor necrosis factor-alpha and lipopolysaccharide. Journal of Pharmaceutical Sciences 2007, 96:2795-2807.

64. Schwartz RH: T cell anergy. Annual Review of Immunology 2003 2I:305-334.

65. Krasnov A, Koskinen H, Rexroad C, Afanasyev S, Molsa H, Oikari A Transcriptome responses to carbon tetrachloride and pyrene in the kidney and liver of juvenile rainbow trout (Oncorhynchus mykiss). Aquatic Toxicology 2005, 74:70-8I.

66. Bowers JM, Mustafa A, Speare DJ, Conboy GA, Brimacombe M, Sims $D E$, et al:: The physiological response of Atlantic salmon, Salmo salar L., to a single experimental challenge with sea lice, Lepeophtheirus salmonis. Journal of Fish Diseases 2000 23:165-172.

67. MacKenzie S, Iliev D, Liarte C, Koskinen H, Planas JV, Goetz FW, et al.: Transcriptional analysis of LPS-stimulated activation of trout (Oncorhynchus mykiss) monocyte/macrophage cells in primary culture treated with cortisol. Molecular Immunology 2006, 43:1340-1348.

68. Loke P, Nair MG, Parkinson J, Guiliano D, Blaxter M, Allen JE: IL-4 dependent alternatively-activated macrophages have a distinctive in vivo gene expression phenotype. BMC Immunol 2002, 3:7.

69. Sandler NG, Mentink-Kane MM, Cheever AW, Wynn TA: Globa gene expression profiles during acute pathogen-induced pul- monary inflammation reveal divergent roles for ThI and Th2 responses in tissue repair. Journal of Immunology 2003, | 7 |:3655-3667.

70. Anthony RM, Rutitzky LI, Urban JF, Stadecker MJ, Gause WC: Protective immune mechanisms in helminth infection. Nature Reviews Immunology 2007, 7:975-987.

7I. Maizels RM, Yazdanbakhsh M: Immune regulation by helminth parasites: Cellular and molecular mechanisms. Nature Reviews Immunology 2003, 3:733-744

72. Loke P, Gallagher L, Nair MG, Zang X, Brombacher F, Mohrs M, et al: Alternative activation is an innate response to injury that requires CD4(+) $\mathrm{T}$ cells to be sustained during chronic infection. Journal of Immunology 2007, I 79:3926-3936.

73. Romagnani S: Regulation of the $\mathbf{T}$ cell response. Clinical and Experimental Allergy 2006, 36:1357-1366.

74. Belkaid Y, Blank RB, Suffia I: Natural regulatory T cells and parasites: a common quest for host homeostasis. Immunological Reviews 2006, 2 I 2:287-300.

75. Diaz A, Allen JE: Mapping immune response profiles: the emerging scenario from helminth immunology. Eur J Immunol 2007, 37:3319-3326.

76. Cliffe LJ, Humphreys NE, Lane TE, Potten CS, Booth C, Grencis RK: Accelerated intestinal epithelial cell turnover: A new mechanism of parasite expulsion. Science 2005, 308: | 463-| 465.

77. Jones SRM: The occurrence and mechanisms of innate immunity against parasites in fish. Developmental and Comparative Immunology 200I, 25:84I-852.

78. Mulcahy G, O'Neill S, Fanning J, McCarthy E, Sekiya M: Tissue migration by parasitic helminths - an immunoevasive strategy? Trends in Parasitology 2005, 2 I :273-277.

79. $\mathrm{Bi}$ Y, Liu G, Yang R: Th I 7 cell induction and immune regulatory effects. J Cell Physiol 2007, 2 I I:273-278.

80. Savan R, Sakai M: Genomics of fish cytokines. Comparative Bio chemistry and Physiology D-Genomics \& Proteomics 2006, I:89-I0I

81. Tsutsui S, Nakamura $O$, Watanabe T: Lamprey (Lethenteron japonicum) IL- I 7 upregulated by LPS-stimulation in the skin cells. Immunogenetics 2007, 59:873-882.

82. Witowski J, Pawlaczyk K, Breborowicz A, Scheuren A, Kuzlan-Pawlaczyk M, Wisniewska J, et al.: IL-I 7 stimulates intraperitoneal neutrophil infiltration through the release of GRO alpha chemokine from mesothelial cells. Journal of Immunology 2000 , | 65:58|4-582|.

83. Ouyang WJ, Kolls JK, Zheng Y: The biological functions of $\mathbf{T}$ helper 17 cell effector cytokines in inflammation. Immunity 2008, 28:454-467.

84. Bird S, Zou J, Secombes CJ: Advances in fish cytokine biology give clues to the evolution of a complex network. Current Pharmaceutical Design 2006, 12:305 I-3069.

85. Plouffe DA, Hanington PC, Walsh JG, Wilson EC, Belosevic M: Comparison of select innate immune mechanisms of fish and mammals. Xenotransplantation 2005, 12:266-277.

86. Whyte SK: The innate immune response of finfish - a review of current knowledge. Fish Shellfish Immunol 2007, 23: I I 27- I I I I.

87. Bird S, Zou J, Savan R, Kono T, Sakai M, Woo J, et al.: Characterisation and expression analysis of an interleukin 6 hornologue in the Japanese pufferfish, Fugu rubripes. Developmental and Comparative Immunology 2005, 29:775-789.

88. Iliev DB, Castellana B, MacKenzie S, Planas JV, Goetz FW: Cloning and expression analysis of an IL-6 homolog in rainbow trout (Oncorhynchus mykiss). Molecular Immunology 2007, 44: $1803-1807$.

89. Yoshiura Y, Kiryu I, Fujiwara A, Suetake H, Suzuki Y, Nakanishi T, et al.: Identification and characterization of Fugu orthologues of mammalian interleukin-I2 subunits. Immunogenetics 2003, 55:296-306

90. Inoue Y, Kamota S, Itoa K, Yoshiura Y, Ototake M, Moritomo T, et al: Molecular cloning and expression analysis of rainbow trout (Oncorhynchus mykiss) interleukin- 10 cDNAs. Fish \& Shellfish Immunology 2005, I 8:335-344.

9I. Lutfalla G, Crollius HR, Stange-thomann N, Jaillon O, Mogensen K, Monneron D: Comparative genomic analysis reveals independent expansion of a lineage-specific gene family in vertebrates: The class II cytokine receptors and their ligands in mammals and fish. Bmc Genomics 2003, 4:

92. Savan $R$, Igawa $D$, Sakai $M$ : Cloning, characterization and expression analysis of interleukin- 10 from the common carp, 
Cyprinus carpio L. European Journal of Biochemistry 2003, 270:4647-4654.

93. Zou J, Clark MS, Secombes CJ: Characterisation, expression and promoter analysis of an interleukin 10 homologue in the puffer fish, Fugu rubripes. Immunogenetics 2003, 55:325-335.

94. Li JH, Shao JZ, Xiang LX, Wen Y: Cloning, characterization and expression analysis of pufferfish interleukin-4 cDNA: The first evidence of Th2-type cytokine in fish. Molecular Immunology 2007, 44:2078-2086

95. Takizawa F, Araki K, Kobayashi I, Moritomo T, Ototake M, Nakanishi $\mathrm{T}$ : Molecular cloning and expression analysis of T-bet in ginbuna crucian carp (Carassius auratus langsdorfii). Mol Immunol 2008, 45: I27-136.

96. Takizawa F, Mizunaga Y, Araki K, Moritomo T, Ototake M, Nakanishi T: GATA3 mRNA in ginbuna crucian carp (Carassius auratus langsdorfii): cDNA cloning, splice variants and expression analysis. Dev Comp Immunol 2008, 32:898-907.

97. Evans HG, Suddason T, Jackson I, Taams LS, Lord GM: Optimal induction of $T$ helper 17 cells in humans requires $T$ cell receptor ligation in the context of Toll-like receptor-activated monocytes. Proc Natl Acad Sci USA 2007, 104:17034-17039.

98. Keir ME, Butte MJ, Freeman GJ, Sharpel AH: PD-I and its ligands in tolerance and immunity. Annual Review of Immunology 2008, 26:677-704

99. Cantorna MT, Nashold FE, Hayes CE: In Vitamin-A-Deficiency Multiple Mechanisms Establish A Regulatory T-Helper Cell Imbalance with Excess ThI and Insufficient Th2 Function. Journal of Immunology 1994, I 52: I5 I 5- I522.

100. Iwata M, Eshima Y, Kagechika H: Retinoic acids exert direct effects on $T$ cells to suppress $T(h) I$ development and enhance $T(h) 2$ development via retinoic acid receptors. International Immunology 2003, 15:1017-1025.

10I. Stephensen CB, Jiang XW, Freytag T: Vitamin A deficiency increases the in vivo development of IL- 10 -positive Th2 cells and decreases development of ThI cells in mice. Journal of Nutrition 2004, 134:2660-2666.

102. Elias KM, Laurence A, Davidson TS, Stephens G, Kanno Y, Shevach EM, et al:: Retinoic acid inhibits ThI7 polarization and enhances FoxP3 expression through a Stat-3/Stat-5 independent signaling pathway. Blood 2008, I I I:10 I3-1020.

103. Kennedy M: The Nematode Polyprotein Allergens/Antigens. Parasitology Today 2000, 16:373-380.

104. Bradley JE, Nirmalan N, Klager SL, Faulkner H, Kennedy MW: River blindness: a role for parasite retinoid-binding proteins in the generation of pathology? Trends in Parasitology 200 I, 17:47I-475.

105. Szanto A, Benko S, Szatmari I, Balint BL, Furtos I, Ruhl R, et al.: Transcriptional regulation of human CYP27 integrates retinoid, peroxisome proliferator-activated receptor, and liver $x$ receptor signaling in macrophages. Molecular and Cellular Biology 2004, 24:8154-8166.

106. Jankovic D, Trinchieri G: IL- I 0 or not IL- I 0: that is the question. Nature Immunology 2007, 8: I 28I-I 283.

107. Mucida D, Park Y, Kim G, Turovskaya O, Scott I, Kronenberg M, et al.: Reciprocal $\mathbf{T}(\mathbf{H}) \mid \mathbf{7}$ and regulatory $\mathbf{T}$ cell differentiation mediated by retinoic acid. Science 2007, 317:256-260.

108. Fast MD, Burka JF, Johnson SC, Ross NW: Enzymes released from Lepeophtheirus salmonis in response to mucus from different salmonids. Journal of Parasitology 2003, 89:7-13.

109. Fast MD, Ross NW, Craft CA, Locke SJ, MacKinnon SL, Johnson SC: Lepeophtheirus salmonis: characterization of prostaglandin E-2 in secretory products of the salmon louse by RP-HPLC and mass spectrometry. Experimental Parasitology 2004, I 07:5-13.

110. Fast MD, Johnson SC, Eddy TD, Pinto D, Ross NW: Lepeophtheirus salmonis secretory/excretory products and their effects on Atlantic salmon immune gene regulation. Parasite Immunology 2007, 29: 179-189.

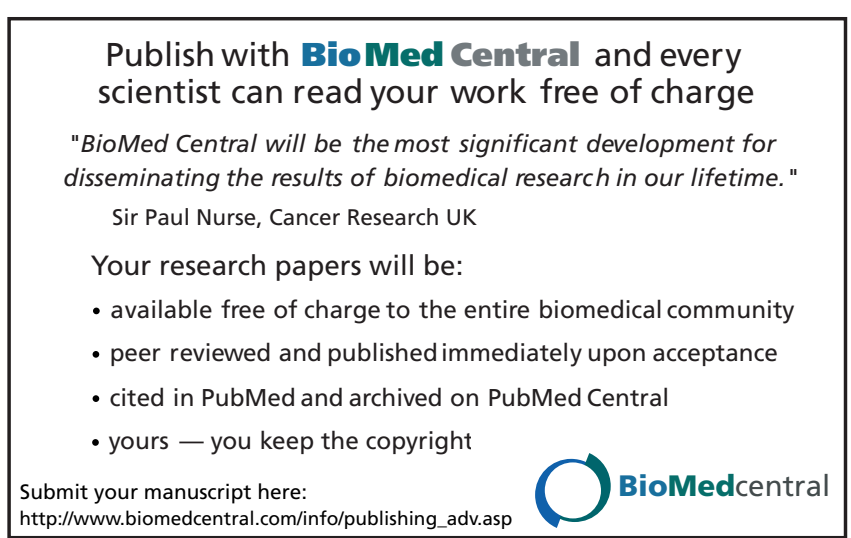

